\title{
Analysis of Decay Caused by Soluble Salts in Historical Monuments
}

\author{
M. PIRAK ${ }^{\mathrm{a}^{*}}$, M. GORJI ${ }^{\mathrm{b}}, \mathrm{R} . \mathrm{VAHIDZADE}^{\mathrm{c}}, \mathrm{R} . \mathrm{BAHADORI}^{\mathrm{d}}$ \\ ${ }^{a}$ Preservation and restoration of cultural- historical objects (M.A) (Islamic Azad University Central \\ Tehran Branch). Tehran, IRAN \\ ${ }^{b}$ Head of conservation department of National Museum. Tehran, IRAN \\ 'Head of conservation department, art \& architecture faculty, Islamic Azad University Central Tehran \\ Branch. Tehran, IRAN \\ ${ }^{d}$ Staff member of Iranian Research Center for Cultural Heritage and Tourism. Tehran, IRAN
}

\begin{abstract}
This paper is based on a research on the problems of salt attack and rising damp in heritage masonry buildings. Amongst common building defects occurrences in heritage buildings, salt attack and rising damp are considered as the most challenging, particularly in building conservation. Rising damp and salt attack, a worldwide phenomenon, are major causes of decay to masonry materials. Moisture and salts in masonry walls can result in damage. The presence of water-soluble salts in porous building materials is one of the principal problems of conservation. Salt attack and rising damp together pose a serious threat to buildings especially with regard to load-bearing walls constructed of brick, stone and mortar. The problem of salt attack is closely associated with rising damp. On its own, rising damp can make buildings unsightly and unpleasant to occupy. The situation is made much worse if there are appreciable quantities of soluble salts present, because the rising damp will carry salts up into the masonry to where the damp evaporates. Moisture from the rising damp makes the salts existing in the building material soluble, or the ground water which contains salts finds its ways through the building wall. Salt damp is caused when moisture from the ground is carried up into the wall of a building. This process involves the movement of water from a high concentration, being the ground, to a low concentration, being the porous wall, which is called capillary action. Rising damp occurs as a result of capillary suction of moisture from the ground into porous masonry building materials such as stone, brick, earth and mortar. They may cause unsightly deterioration of building exteriors and interiors as well as possible building structure failures if left untreated. Their crystallization is in fact the cause of those phenomena of deterioration that so often appear on surfaces: lack of cohesion, scaling, flaking and bulging. When the water transporting the salts through porous materials evaporates, due, for example, to changing climatic conditions, the solution becomes more concentrated. As soon as it becomes supersaturated, the salts crystallize giving rise to both efflorescences on the surface and/or sub-efflorescences below the surface layer. The impact of salt damp is often worse on external wall surfaces, especially those exposed to direct sunlight, where evaporation is higher. This moisture then evaporates on or just below the wall surface leaving the salt residues behind. There the salts are left behind and can often be seen as a white efflorescence on the wall surface. When these salts grow as crystals within the pores of the masonry they can disrupt even the strongest material, leading to fretting and crumbling of the surface. These formations gradually contribute to building dilapidation and reduce the building aesthetic values. The telltale signs of salt attack in a wall are: fretting mortar or stone or brick, bubbling paint, crumbling plaster, and the presence of moisture on the surface of the wall. It is very important to know the salt content of deteriorated surfaces both to understand the causes of decay and plan conservation strategies. The nature of the salt provides us with information
\end{abstract}

* _ Corresponding author: pirak.p.r@gmail.com 


\section{Vol. 1, No. 2, Semi-Annual Autumn \& Winter 2015-2016}

about its origin and therefore, indicates the possible conservation treatment to adopt. Sources of salts can be the building materials themselves (sand, bricks, mortar), or external sources (soil, materials used for conservation treatment, pollutants in the atmosphere, sea spray, de-icing salts scattered on roads in winter, and products generated by the metabolism of micro- organisms). The results of this research showed that almost all masonry contains soluble salts, principally sulphates, nitrates, chlorides and carbonates of sodium, potassium, calcium, magnesium and ammonium and so, all liquid water present in walls is more or less a diluted salt solution. Sources of these salts may be natural or human induced. But, not all salts generate decay. This depends on their solubility, hygroscopicity, mobility and the hydration level of their crystalline form.

Keywords: Building defects, Effloresce, Rising damp, Salt attack, Pathology, Conservation. 


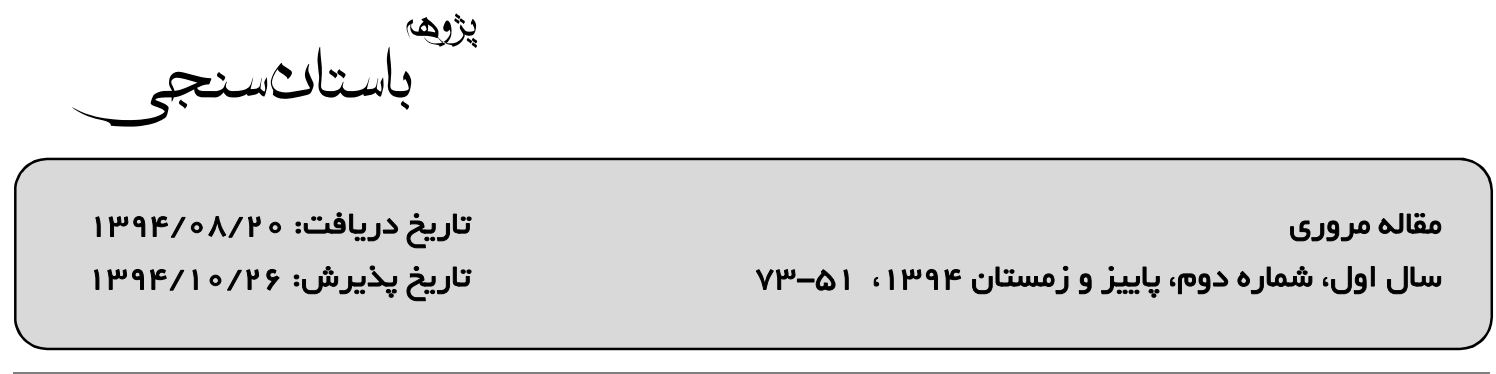

بررسى مكانيسم تخريب ناشى از نمكهاى محلول در بناهاى تاريخى

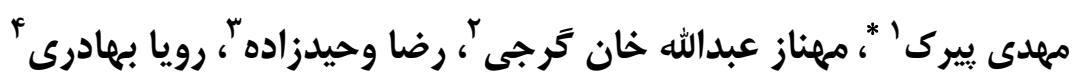

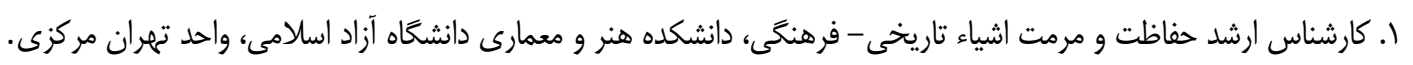

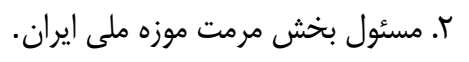

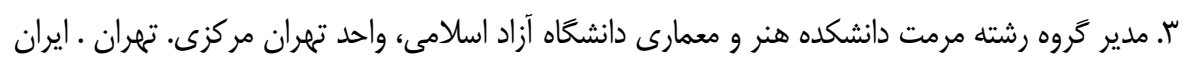

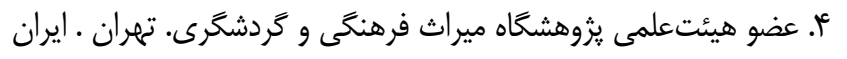

"جكيده

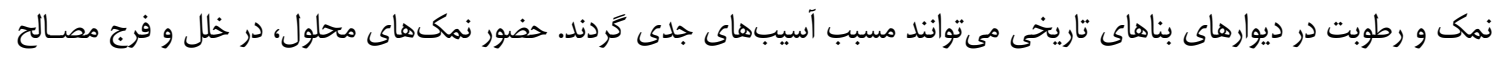

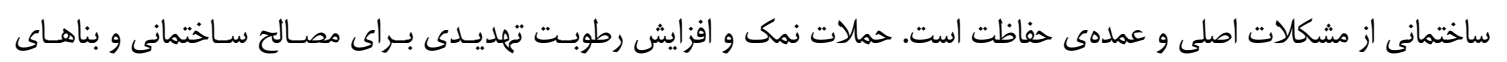

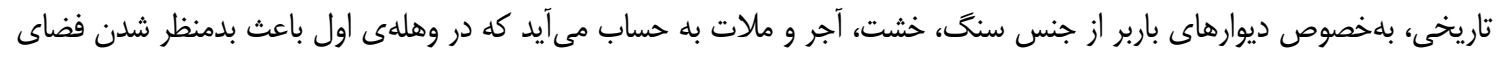

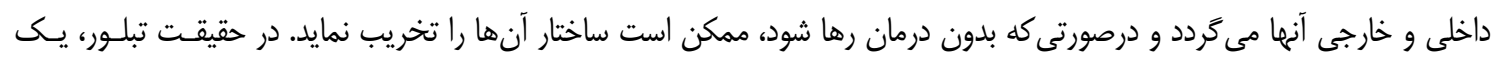

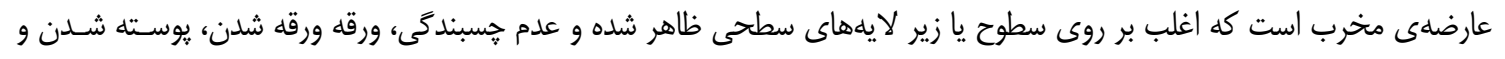

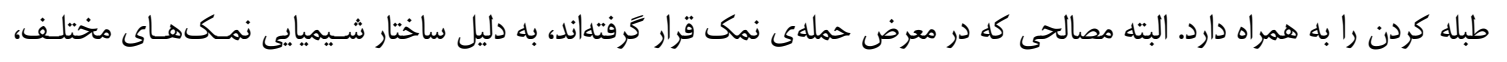

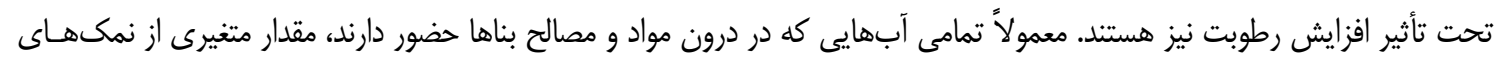

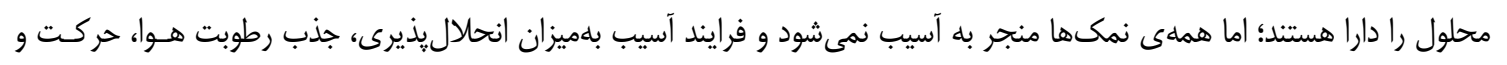

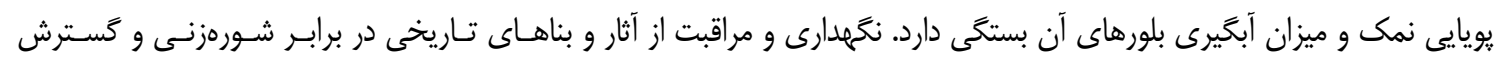

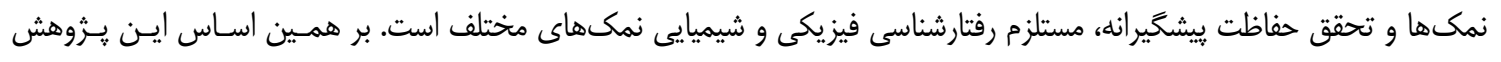

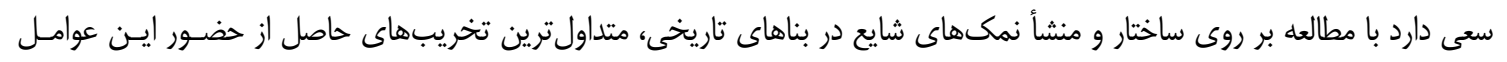

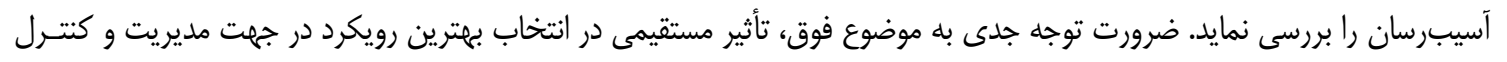

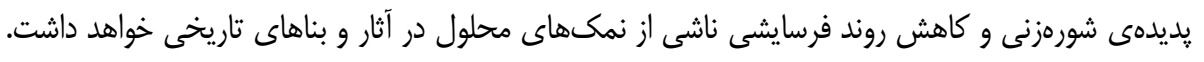

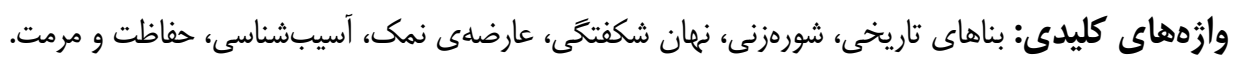

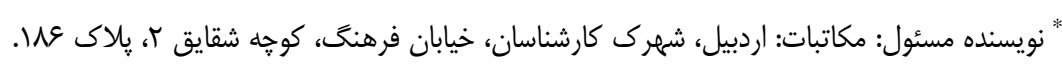
pirak.p.r@gmail.com : پَست الكترونيك:

C) حق نشر متعلق به نويسنده(كان) است و نويسنده تحت مجوز Creative Commons Attribution License به مجله اجازه مىدهد مقاله حإ شده

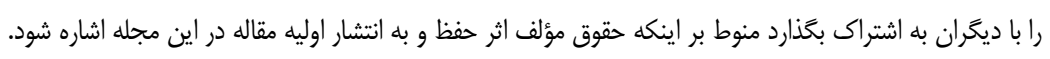


بلهور معمول، يا در اثر واكنش با ساير عناصـر موجـود در درون مواد و مصالح و يا تركيبـات موجـود در جـوّ ظـاهر

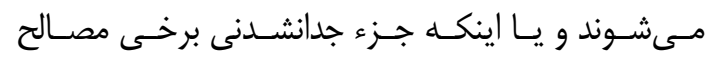

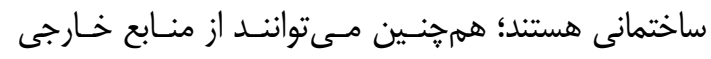

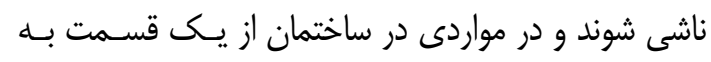

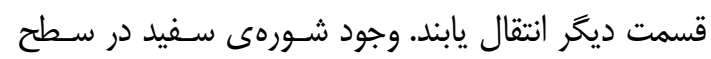

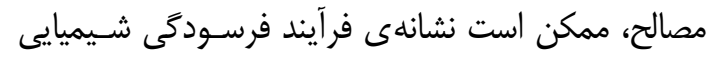

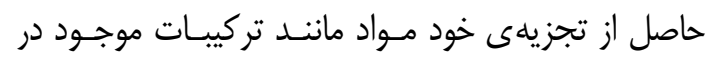

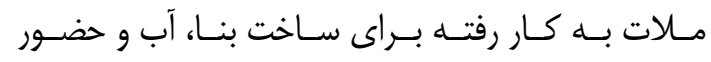

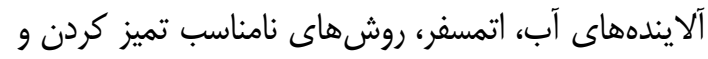

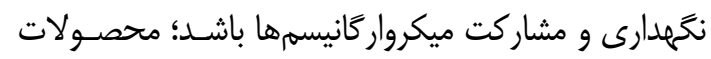

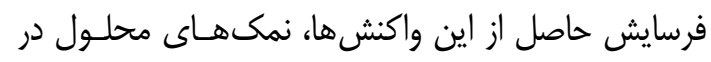

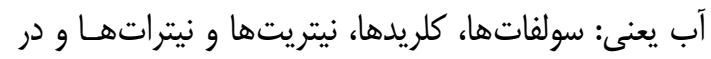

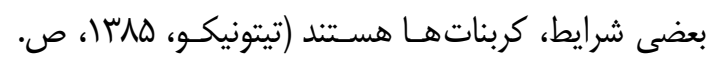

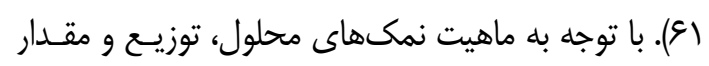

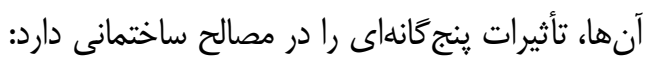

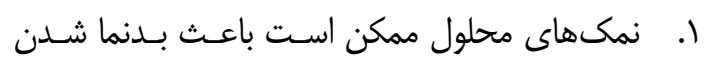

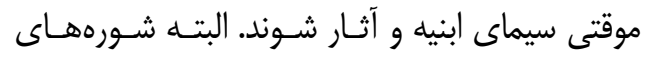

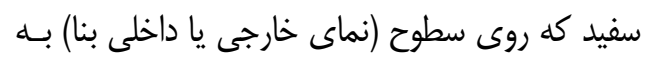

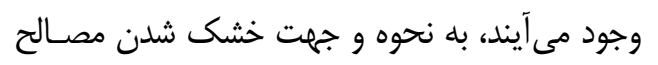
نيز بستخى دارد. ז. نمكهاى محلول ممكن است به شكل كريستالى، از

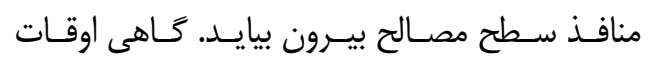

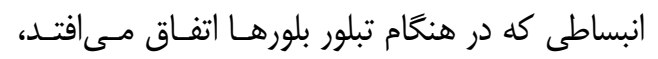
باعث ايجاد ترك در مصالح مسىشـود. ايـن انبسـاط

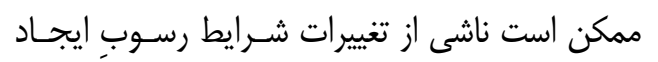

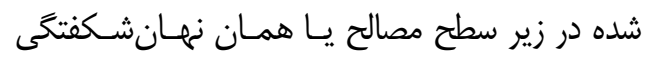
باشد (Brooks, 2008, p. 1).

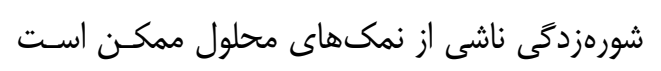

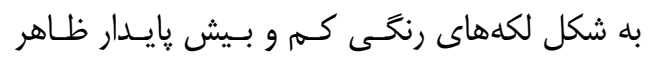
f. نمكها ممكن است يك يوستهى شيشـاى سـخت

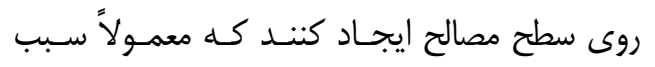

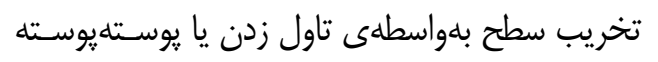

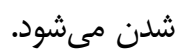
ه. نمكهاى محلول ممكن است با تركيبات مشخصى
- - - - مقدمه

شوره، رسوب نمكهاى محلول در آب اسـت كـه در اثر

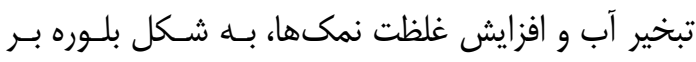

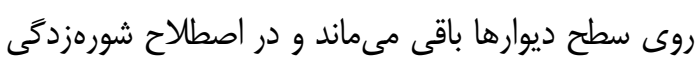

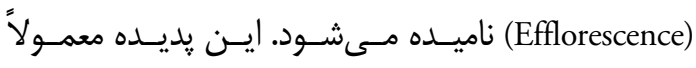

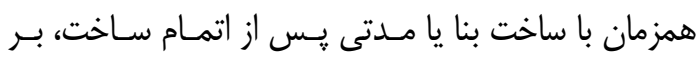

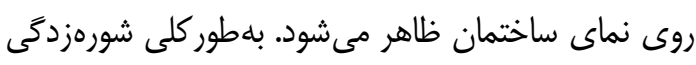

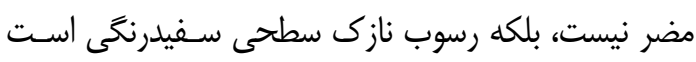
كه به نظر مىرسد فقط يك تغيير سطحى ظاهرى در بنـا ايجاد كند درحالى كه بررسى عميقتر شـورهزدخى نشى نشـان

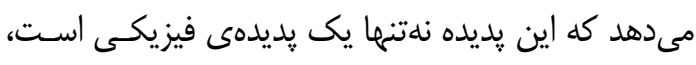

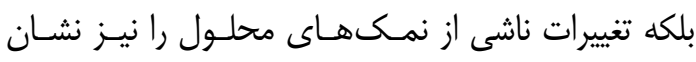
مى دهد و ممكن است به كنش هاى شيميايى كـه بعـــاً در

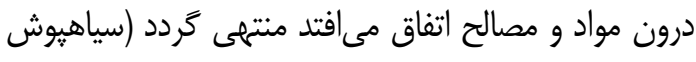

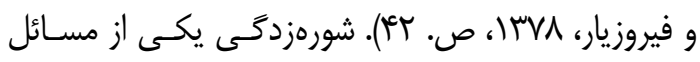

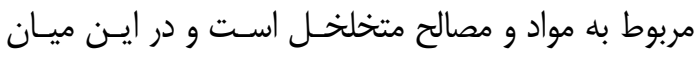
رطوبت نقش اصلى در حركت و جابهجـايى نمـكهــا دارد

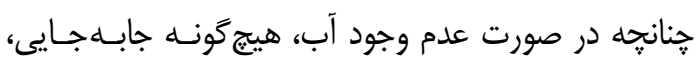

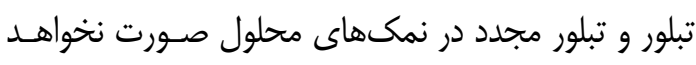
كَرفت.

نماى خارجى بناها بلخصوص بناهاى خشتى، آجرى،

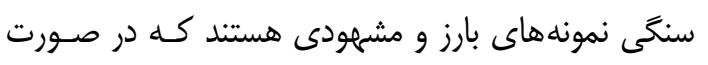

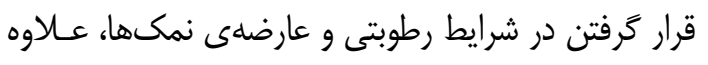

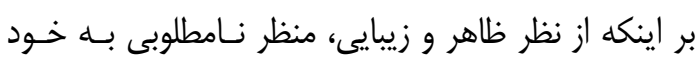

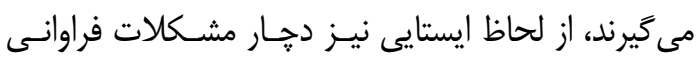

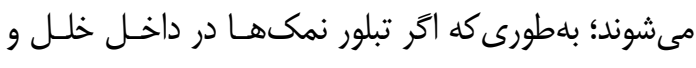

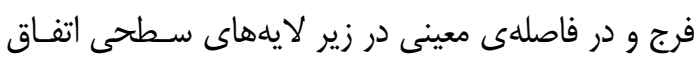

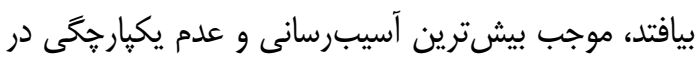

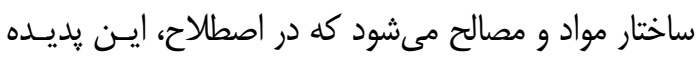

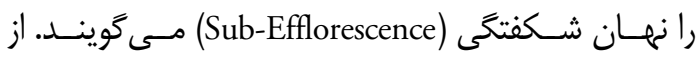

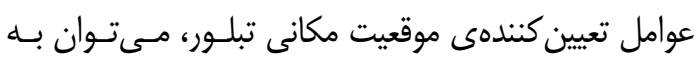

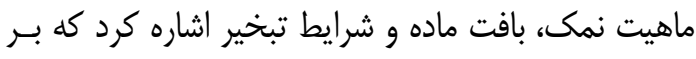

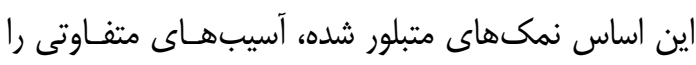

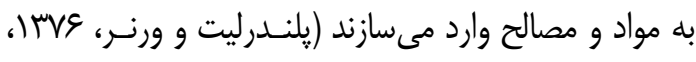

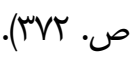
اغلب نمكها غير از آنهايى كه از ابتدا وجود دارنـد، 
تدابير لازم، تجزيه و تحليل هر موقعيت يا هر موردى كـهـ

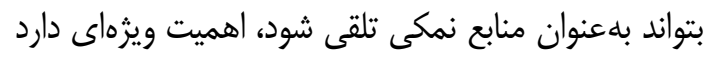

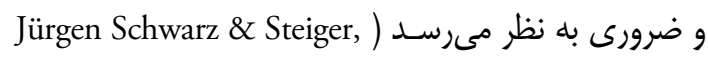
.(2008, p. 127 در اين :ثزوهش سعى بر آن اسـت تـا بـا مـرورى بــر

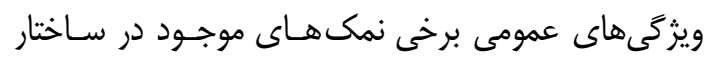

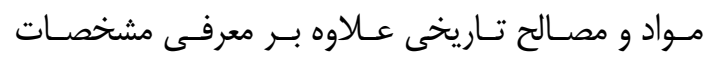

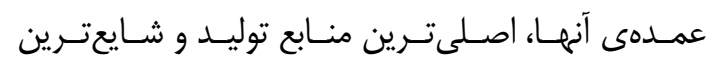

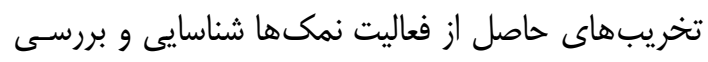

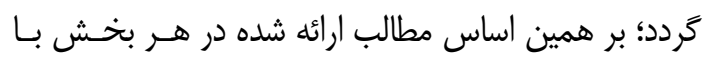

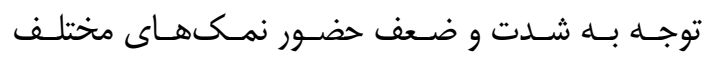
كردآورى و تنظيم شده است.

\section{r - مشخصات عمومى نمكها}

نمك از كاتيونهاى مثبت و آنيونهاى منفى تشكيل شده

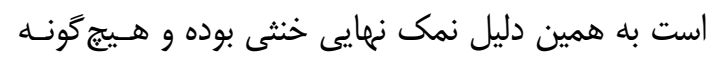

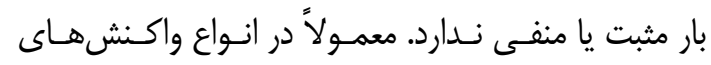

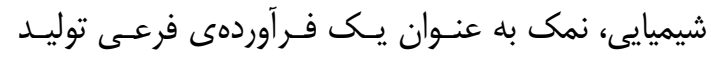

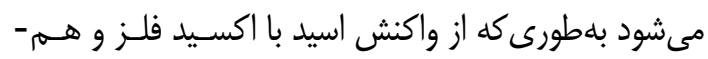
جنين باز با اسيد، نمك و آب حاصل مى شود و از واكـنش

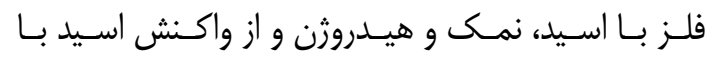
كربناتها، نمك، آب و دى اكسيد كربن تشكيل مئى نـردد.

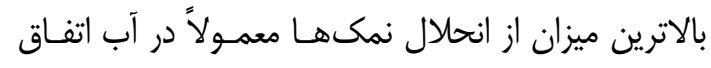

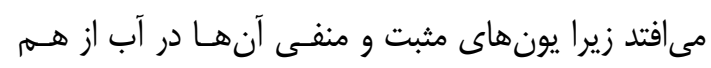

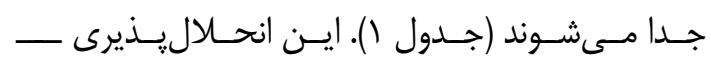

از سيمان يرتلند يا آهكهاى آبى واكنش نشان دهند (ملاتهايى كه در يك دوره جهــت مرمـت اسـتفاده

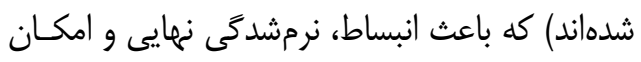
فروياشى مصالح خواهند شد كه اين يديده بــهنــوان

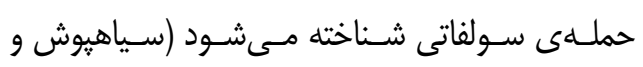

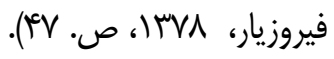

تحـت تـأثير تمـامى عوامـل فـوق، مــواد و مصـالح

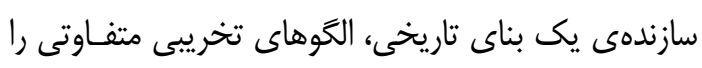

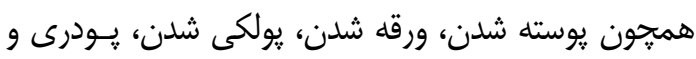

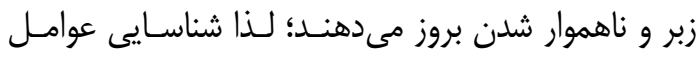

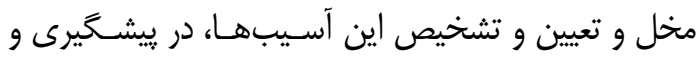
درمان مواد و مصالح و حفاظـت از بناهـاى تـاريخى حسئز

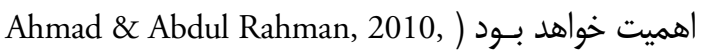

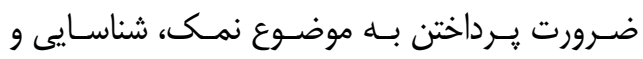

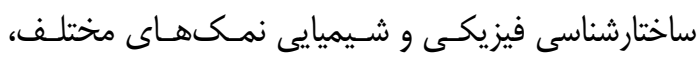

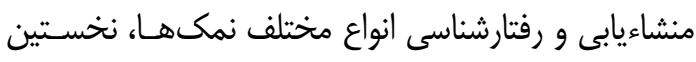

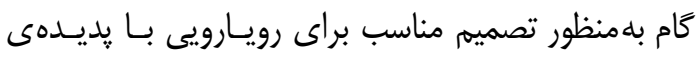

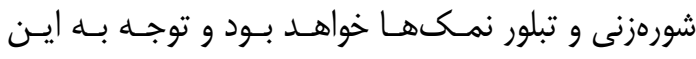

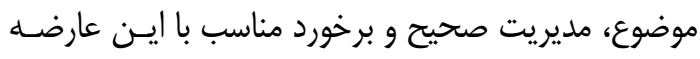

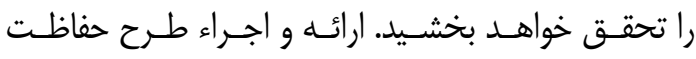
ييشخيرانه و مراقبت از بناهاى تاريخى در برابر آسيبهاي

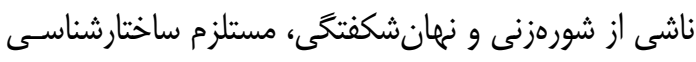

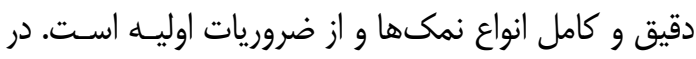

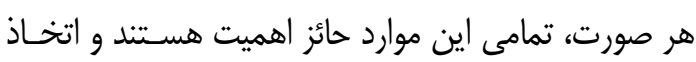

جدول (: انحلال يذيرى تعدادى از نمكها در درجه حرارت مشخص و بر حسب گرم بر ليتر (Borrelli, 1999.p. 4).

\begin{tabular}{|c|c|c|c|}
\hline & انحلال تر & فرمول شيميايى & نمكها \\
\hline 0.015 & $\left(25^{\circ} \mathrm{C}\right)$ & $\mathrm{CaCO}_{3}$ & كلسيت \\
\hline 0.106 & $\left(20^{\circ} \mathrm{C}\right)$ & $\mathrm{MgCO}_{3}$ & مخنزيت \\
\hline 2.58 & $\left(20^{\circ} \mathrm{C}\right)$ & $\mathrm{CaSO}_{4} .2 \mathrm{H}_{2} \mathrm{O}$ & زيِيس \\
\hline 264.0 & $\left(20^{\circ} \mathrm{C}\right)$ & $\mathrm{NaCl}$ & هاليت \\
\hline 363.4 & $\left(20^{\circ} \mathrm{C}\right)$ & $\mathrm{Na}_{2} \mathrm{SO}_{4} \cdot 10 \mathrm{H}_{2} \mathrm{O}$ & ميرابليت \\
\hline 486.5 & $\left(20^{\circ} \mathrm{C}\right)$ & $\mathrm{Na}_{2} \mathrm{CO}_{3} .10 \mathrm{H}_{2} \mathrm{O}$ & ناتريت \\
\hline 595.0 & $\left(0^{\circ} \mathrm{C}\right)$ & $\mathrm{CaCl}_{2}$ & هيدروفليت \\
\hline 921.0 & $\left(25^{\circ} \mathrm{C}\right)$ & $\mathrm{NaNO}_{3}$ & نيتروناتريت \\
\hline 2660.0 & $\left(0^{\circ} \mathrm{C}\right)$ & $\mathrm{Ca}\left(\mathrm{NO}_{3}\right)_{2} \cdot 4 \mathrm{H}_{2} \mathrm{O}$ & نيتروكلسيت \\
\hline
\end{tabular}

$\Delta \mu$ 


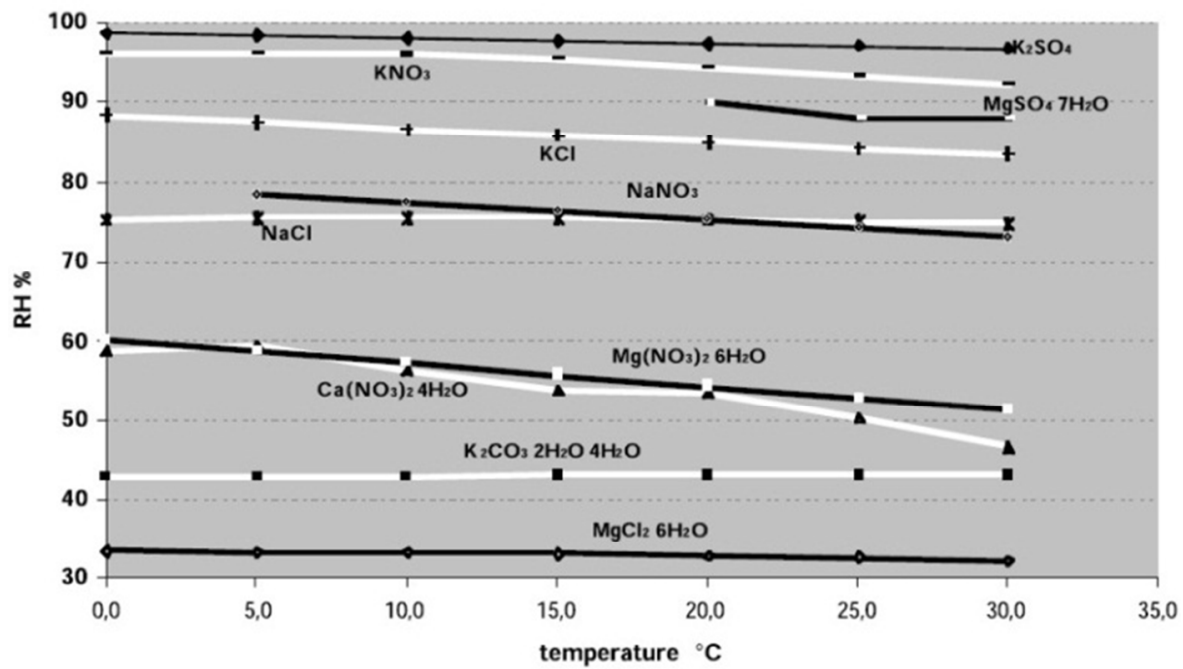

شكل (: رطوبت نسبى تعادل نمكهاى معمول در ديوارها (Borrelli, 1999. p.

صورت مى گيرد كه شـرايطى بـراى بـاقى مانـدن حالـت

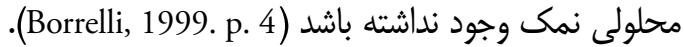

\section{ץ-1 - نمكهاى سولفاته}

سولفاتها (Sulfates) تركيبى از سولفور و اكسيثن بوده و

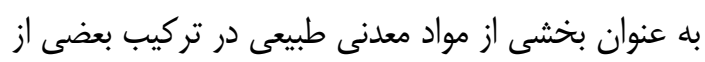
خاكها و سنحَها يافت مىشوند. اين مواد معلنى به به مرور زمان حل شده و در آبهاى زيرزمينى رها مى كردند. در

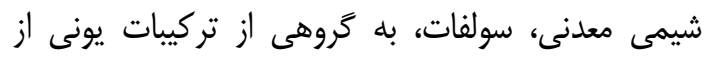
كوخرد كَفته مىشود كه ريشهى نام آن در انغليسى نمكى

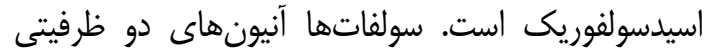
مىباشند و بنيان (SO

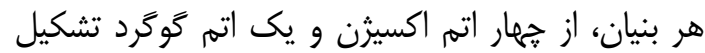

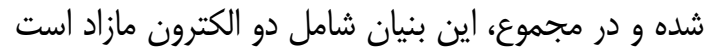
(قريب، MMسا، ص. عسا) (شكل ז).
انحلال يذير: تركيباتى كه در دمـاى

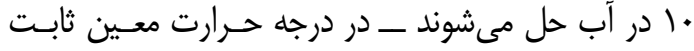

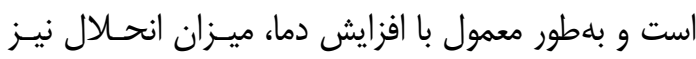
بالا مىرود (حامى، هربا، ص. ها ه). نمكها به دليل دارا بودن اجـزاء يـونى، ايجـاد بلـور

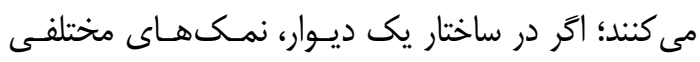
وجود داشته باشد ــمطابق درصد رطوبـت نسـبى تعـادل

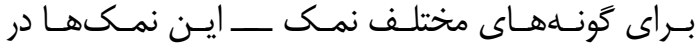
رطوبتهاى نسبى گوناكونى متبلور خواهند شد (شكل ().

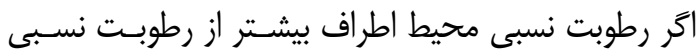
تعادل براى محلــول اشـباع از نمـك باشــ، نمـكـهـا در محلول باقى خواهند ماند و يا اكر به فرم بلورى باشند حل

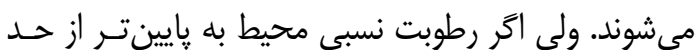
رطوبت نسبى تعادل محلول اشباع از نمك برســـ امكـان

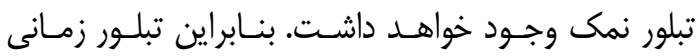
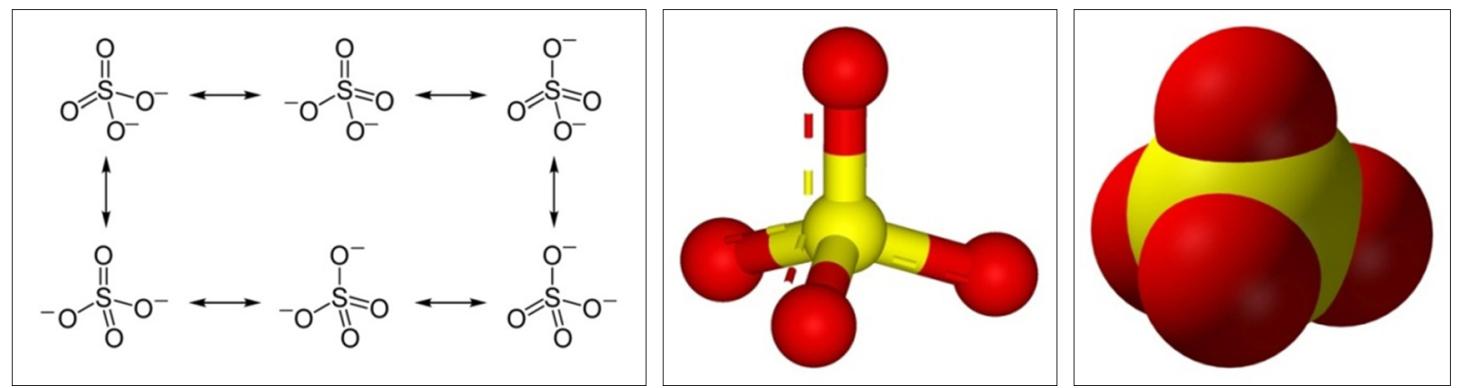

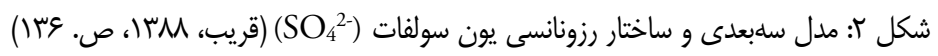


سولفاتها بهطور معمول در ديوارها به شكل سولفات

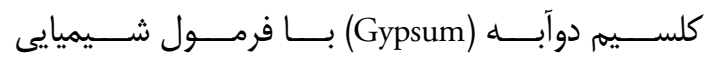
(CaSO $\left.4.2 \mathrm{H}_{2} \mathrm{O}\right)$ فرمول شيميايى $\left(\mathrm{Na}_{2} \mathrm{SO}_{4} \cdot 10 \mathrm{H}_{2} \mathrm{O}\right.$ و به ندرت بهاعنـان

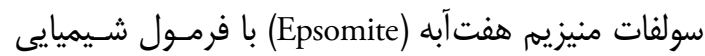
يافـت مـىشــوند؛ ايـن نمـكهــا معمولترين سولفاتهاى يافت شده در مصالح سـاختمانى

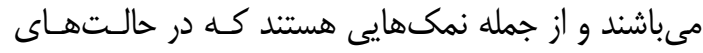

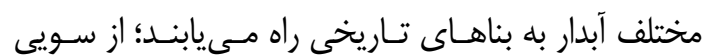
سولفات پتاسيم (Arcanite) با فرمول شـيميايى (K2SO4) بسيار كمياب بوده و ممكن است به مقدار جزئى همراه بـاــا سولفات سديم يافت شود. سولفات منيزيم (MgSO در حالـتهـاى مختلـف آبــار بسـيار نـادر اسـت؛ امـا در قسمتهاى محدودى، نمكى عمده را تشكيل مىدهد. اين

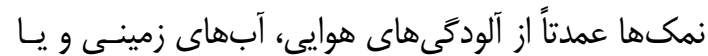

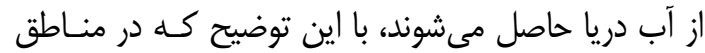
ساحلى همراه با مقادير زيادى كلرور و مقدار كمى سولفات

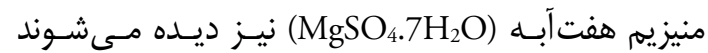

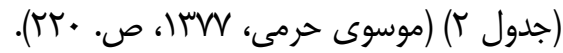

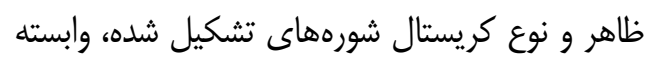
به ماهيت نمكهاى متبلور و ميزان تبخير دارد، بـهعنـوان

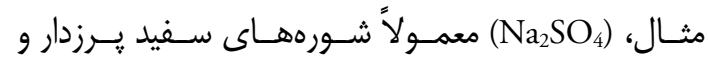
(CaSO 4$)$ r-1 - - - انحلال يذيرى

بيشتر سولفاتهاى فلزى كه داراى آنيون SO هستيند، درى آب محلول بوده ولى از ميان آنها سولفات كلسيم

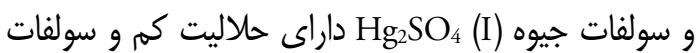
باريم BaSO، سولفات سرب PbSO، سولفات استرانسـيم و و سولفات نقره $\mathrm{SrSO}_{4}$

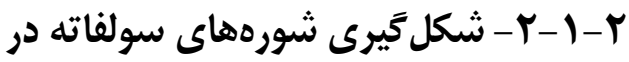 بناهاى تاريخى} سولفاتها نسبت بـهـ سـاير نمـكهــا حلاليـت و تحــرى كمترى دارند و به همين خاطر تنها در فاز اوليهى تشـكيل سليك يعنى موقعى كه هنوز به شكل محلـول هسـتند، در درون

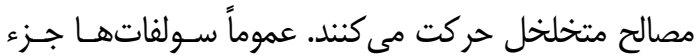
نمكههاى متداول در اغلب مصالح سـاختمانى مس بـاشـند.

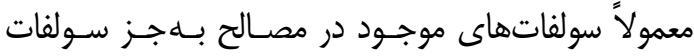

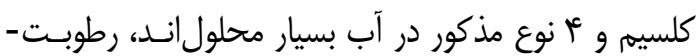

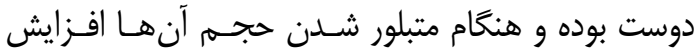
مىيابد؛ اكر جه بلهطور كلى در مقايسه با تركيبات نامحلول، حلاليت سولفات كلسيم در آب محسوس اسـت (حلاليـت

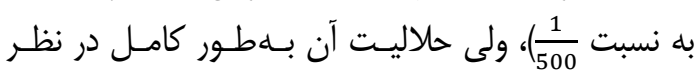

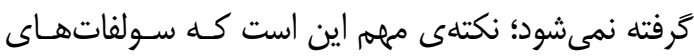

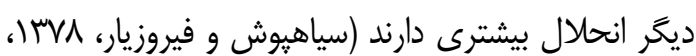

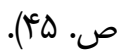

جدول ז: شايعترين سولفاتهاى رسوبى (موسوى حرمى، ITV ص. • •T).

\begin{tabular}{|c|c|c|c|c|}
\hline فرمول & & & حالت & رد \\
\hline $\mathrm{Na}_{2} \mathrm{SO}_{4} \cdot \mathrm{CaSO}_{4}$ & Glauberite & كلابريت & \multirow{4}{*}{ بلدون آب } & \multirow{11}{*}{ سولفاتها } \\
\hline $\mathrm{CaSO}_{4}$ & Anhydrite & انيدريت ان & & \\
\hline $\mathrm{BaSO}_{4}$ & Barite & 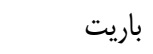 & & \\
\hline $\mathrm{K}_{2} \mathrm{SO}_{4} .2 \mathrm{MgSO}_{4}$ & Langbeinite & لانحَبينيت & & \\
\hline $\mathrm{Na}_{2} \mathrm{SO}_{4} \cdot 10 \mathrm{H}_{2} \mathrm{O}$ & Mirabilite & ميرابيليت & & \\
\hline $\mathrm{MgSO}_{4} \cdot \mathrm{H}_{2} \mathrm{O}$ & Kieserite & كيزريت & & \\
\hline $\mathrm{CaSO}_{4} .2 \mathrm{H}_{2} \mathrm{O}$ & Gypsum & 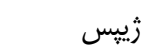 & & \\
\hline $\mathrm{K}_{2} \mathrm{MgCa}_{2}\left(\mathrm{SO}_{4}\right)_{4} \cdot 2 \mathrm{H}_{2} \mathrm{O}$ & Polyhalite & يلى هاليت & آبدار & \\
\hline $\mathrm{MgSO}_{4} \cdot 6 \mathrm{H}_{2} \mathrm{O}$ & Hexahydrite & هخزاهيدريت & & \\
\hline $\mathrm{MgSO}_{4} .7 \mathrm{H}_{2} \mathrm{O}$ & Epsomite & إسوميت & & \\
\hline $\mathrm{MgSO}_{4} \cdot \mathrm{KCl} .3 \mathrm{H}_{2} \mathrm{O}$ & Kainite & كاينيت & & \\
\hline
\end{tabular}




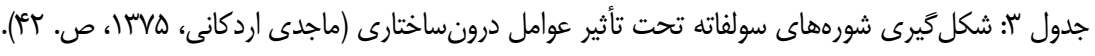

توليد آجر توسط خاك حاوى سولفاتهاى قليايى از جمله يتاسيه، سديم و منيزيم

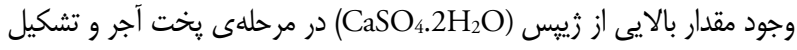

شوره ماى سولفاتهى حاصل از عوامل سولفاتهاى قليايى

حضور سولفاتها با خاصيت جذب آب بالا به مقدار زياد در خاك آجر

اوليه و درونساختارى

حضور ميكروار كانيسمها و احياء سولفور و اكسيدهاى حاصل از آن به سولفاتها

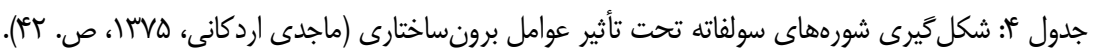

مواد اصلى يا موادى كه در طى دورههاى مختلف حفاظت و مرمت اضافه شده

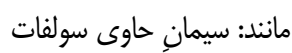

منابع ثانويه و برونساختارى مؤثر در سولفات آمونيوم موجود در زمينهاى كشاورزى

سولفات منيزيم حاصل از اسيرى و ياشيدن آب دريا

تشكيل و ظهور شورههاى سولفاته

حضور ميكروار كانيسمها و احياء سولفور و اكسيدهاى حاصل از آن به سولفاتها

است به حد وسيعى بين انواع مختلف آجـر و حتسى بـين

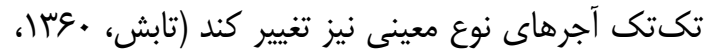

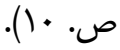

علاوه بر موارد ذكرشده مهـهمترين منبـع سـولفات،

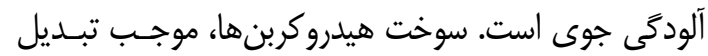
سولفور به دى اكسيد سولفور

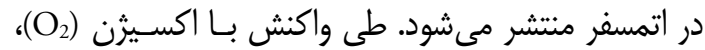

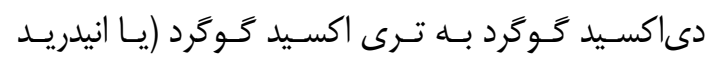

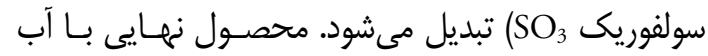

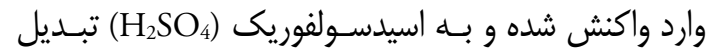

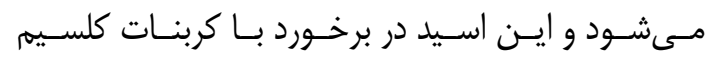
آن را به سولفات كلسيه (CaSO$\left(\mathrm{CaCO}_{3}\right)$ زير تبديل مى كند:

$$
\mathrm{SO}_{3}+\mathrm{H}_{2} \mathrm{O} \rightarrow \mathrm{H}_{2} \mathrm{SO}_{4}
$$

$\mathrm{H}_{2} \mathrm{SO}_{4}+\mathrm{CaCO}_{3} \rightarrow \mathrm{CaSO}_{4}+\mathrm{H}_{2} \mathrm{O}+\mathrm{CO}_{2} \uparrow$

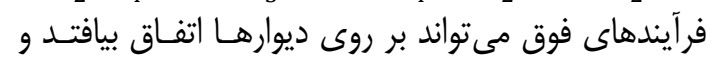
منجر به شكل گَيرى شوره مهاى سولفاته تردد (نمودار ()).

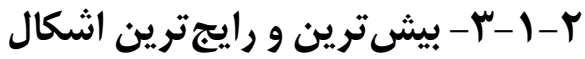 تخريب نمكهاى سولفاته}

آسيب حاصل از سولفاتها به دليل حلاليت آنها در آب لماته
آنها بسيار سخت است. (آموروسـو و فاسـينا، • •

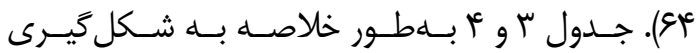
شورههاى سولفاته از منابع درونساختارى و برونساختارى اختصاص داده شده است.

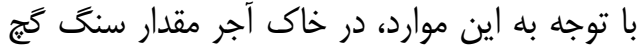

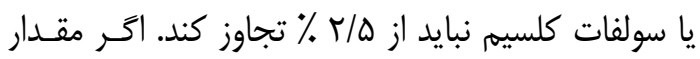

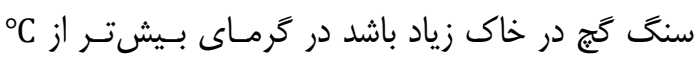

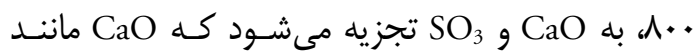

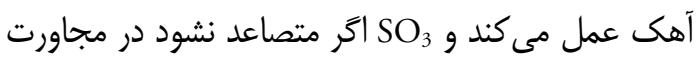
رطوبت به علاوه بر اين، وجود سولفاتهاى منيزيم و يتاسيم نيز به به بهابه علت آبدار شدن، به آجر لطمه مىزنند. لذا مقدار سولفات

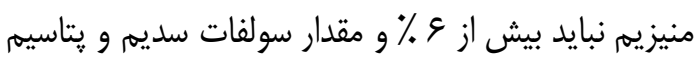
نبايد بيش از ع ٪ باشد. لازم به ذكر است كه سولفاتها

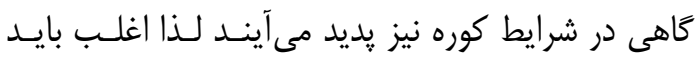

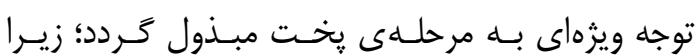

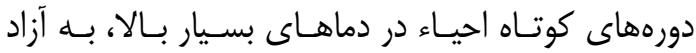
شدن SO و $\mathrm{SO}_{2}$ و در نتيجه تجز يلهى سولفاتهاى مضر

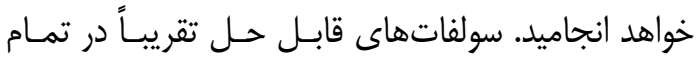
آجرهاى رسى يخته وجود دارند اكرجه مقدار آنها ممكن 


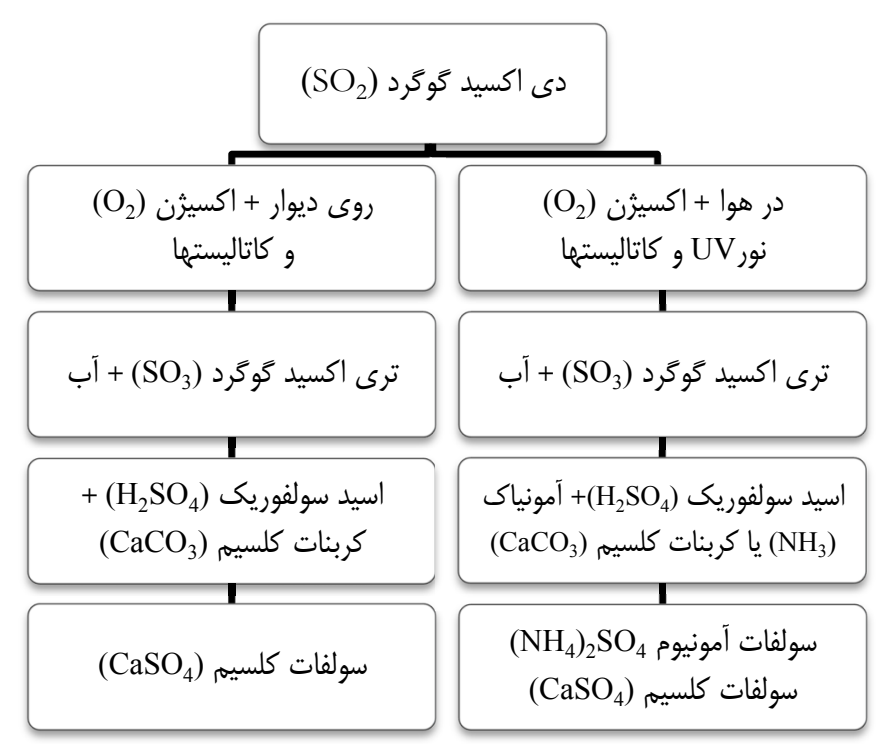

نمودار ا: واكنش دىاكسيد كَّكرد در هواو روى ديوار (تيتونيكو، هشبا، ص. بَ).

دارد (شكلץ)؛ آسيب از ناحيهى سولفاتها فقط زمانى كـهـ

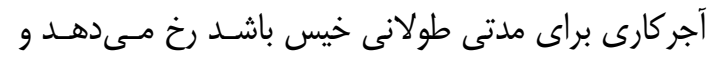

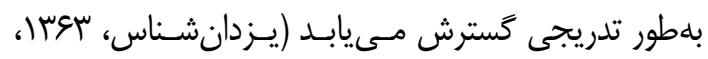

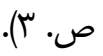
شرايطى را كه مىتواند زمينهساز ظهـور آسـيبهـاى

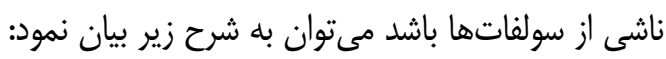

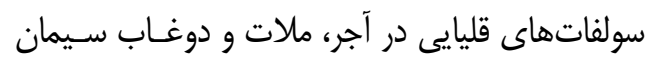
يا هر سه وجـود دارنــــ سـفيدى سـولفاتى مـوقعى بــروز

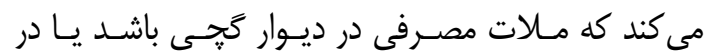

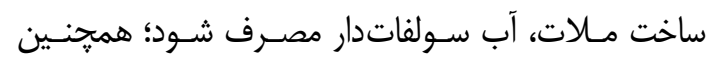

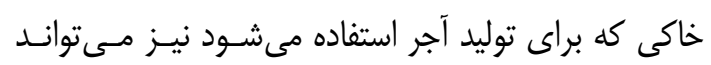

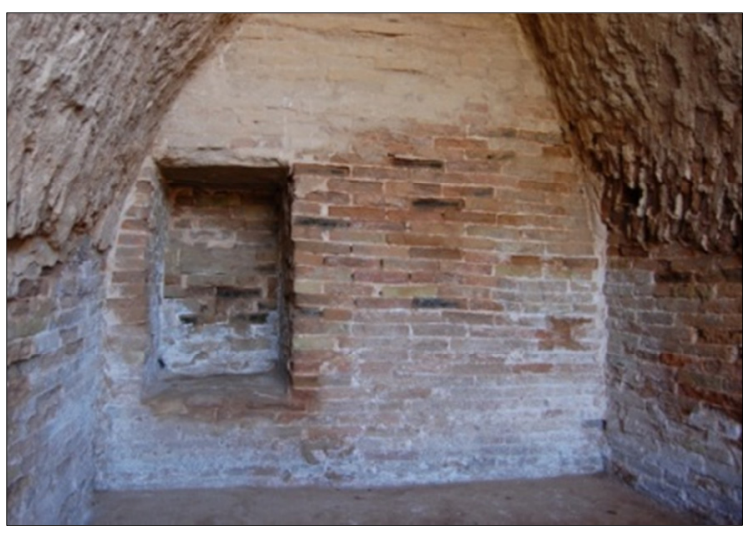

نيست، بلكه بدين خاطر است كه اين مواد در حالـتهـاى

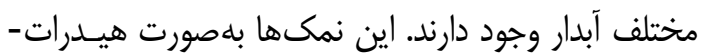
هاى مختلف سـولفات ســيم دها آبـه (

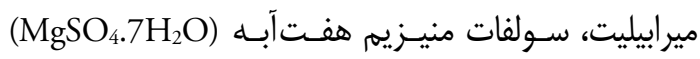
إيوزوميت، سولفات كلسيم دوآبه (CaSO از محلولهاى فوق اشباعشدهى خود، در خلل و فرج مـواد

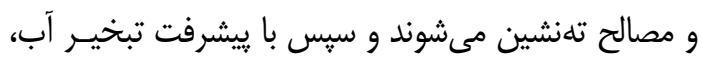

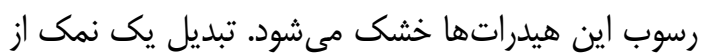

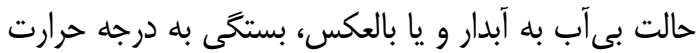

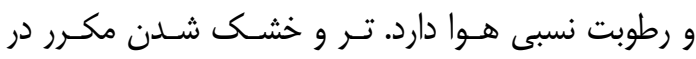

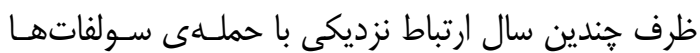

شكل سّ: تشكيل بلورهاى سخت سولفات كلسيم هيدراته بر روى مواد و مصالح ديوارهى جنوب و جنوبغربى آرامكاه هفتتِه؛ مجموعلى ميراث

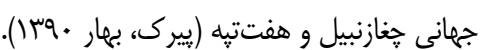

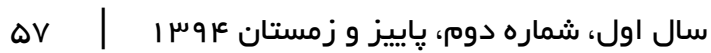


بلورهاى بزرى خواهد شد. - يكى نمك بـى آب موقعى آب مسى ئيـرد كـه فشـار

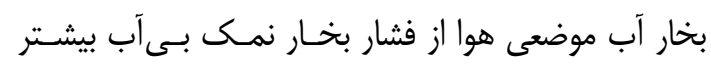

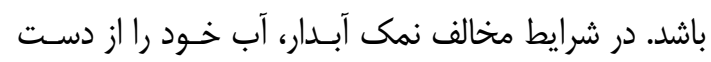

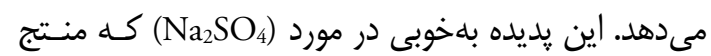
به

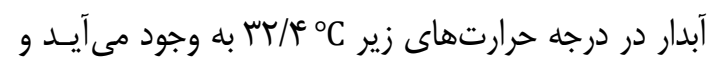

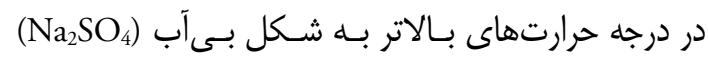

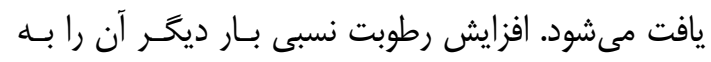

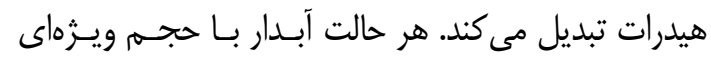

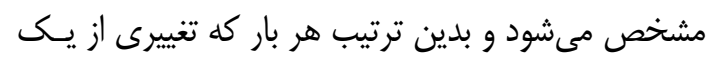

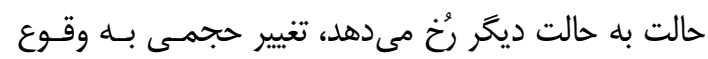

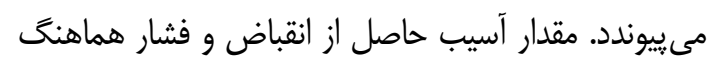

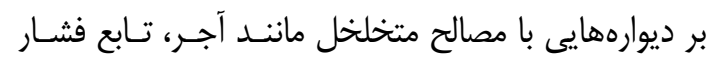

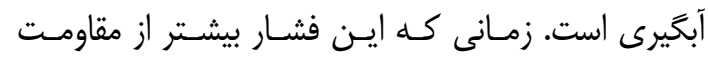

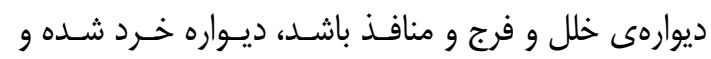

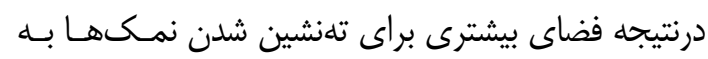

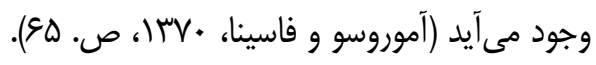

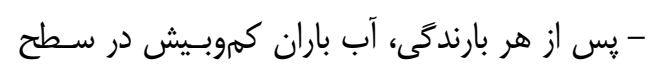

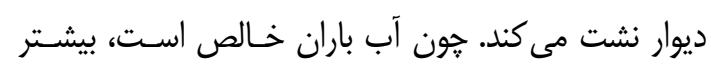

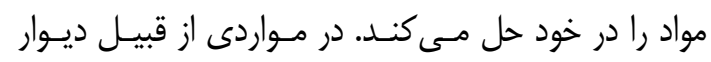

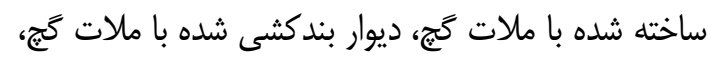

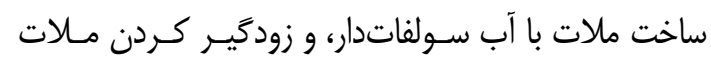

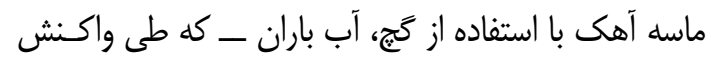

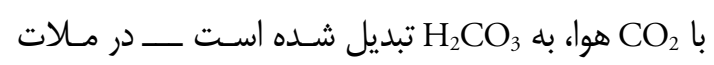

حاوى سولفاتهاى گَوناكون باشـــــ آب بـاران و آبهـاى

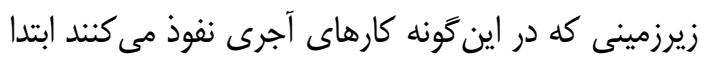

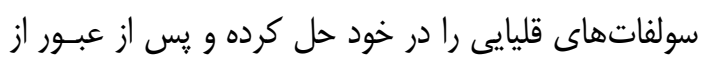

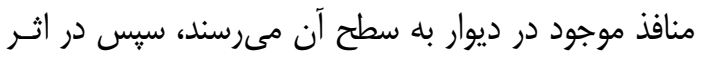

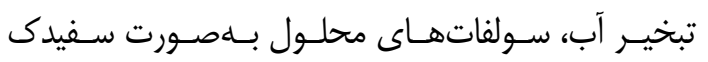

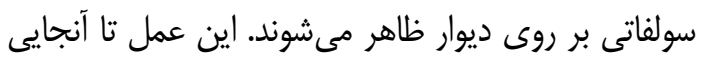

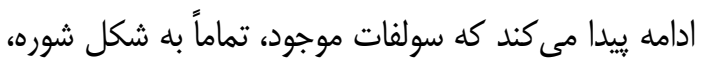
ساختار موادو مصالح را ترك نمايد (سياهيوش و فيروزيار،

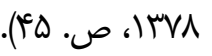

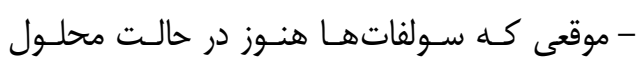

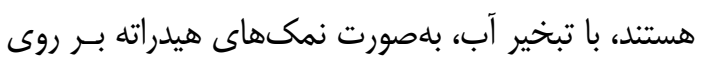

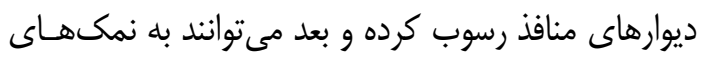

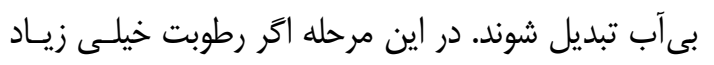

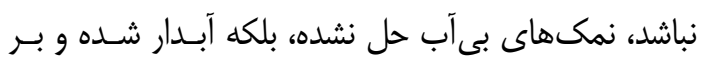

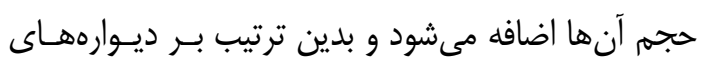

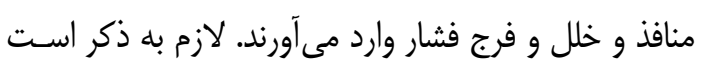

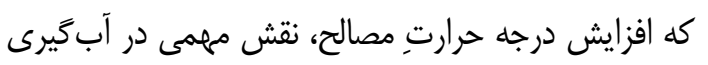

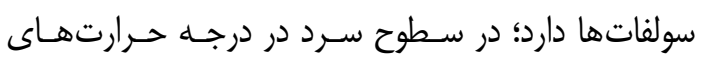

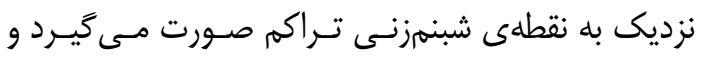

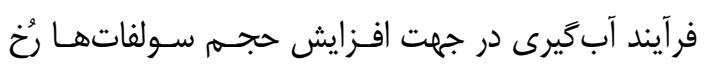

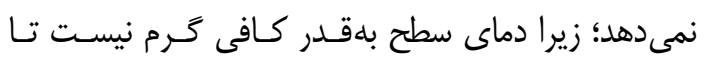

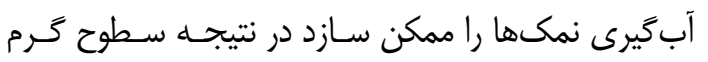

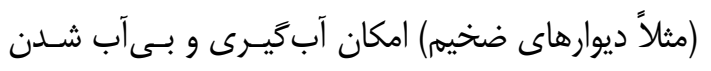

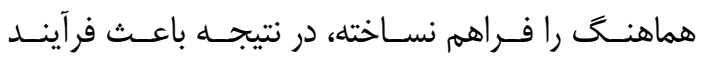

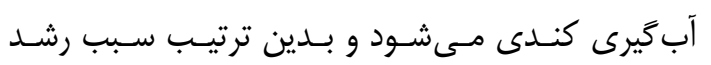
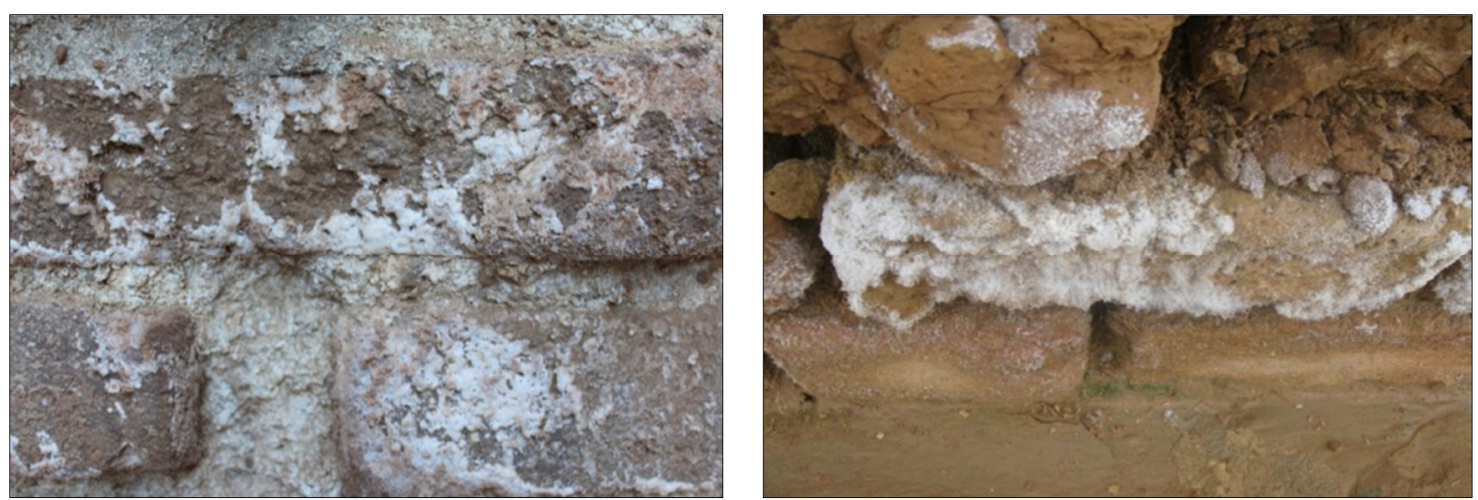

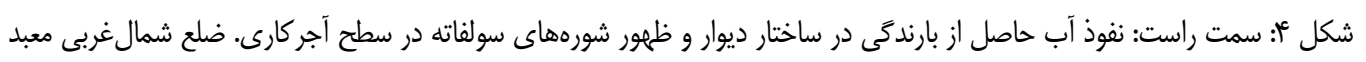

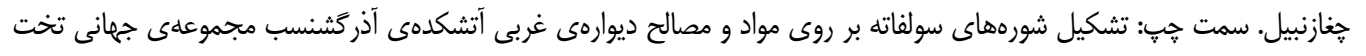

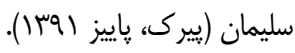


اما ساختمان در معرض حملهى آلودَىهـاى جهوّى قرار

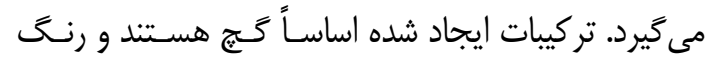

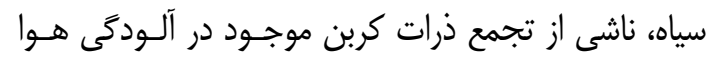

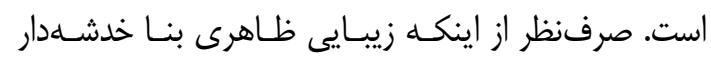

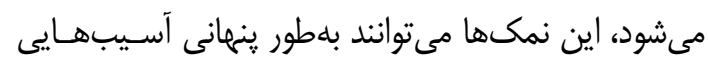

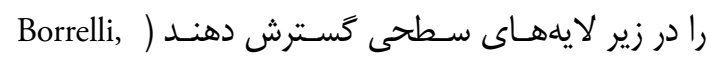

(1999, p. 6

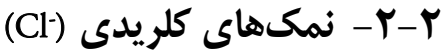

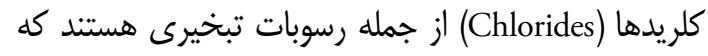

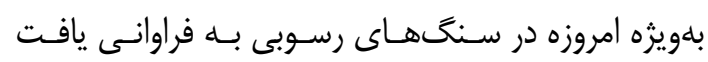

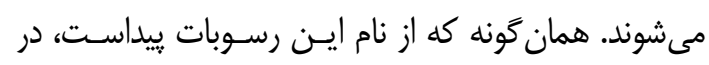

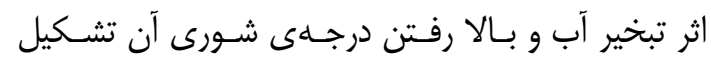

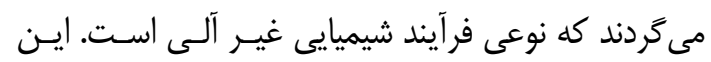

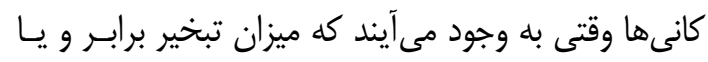

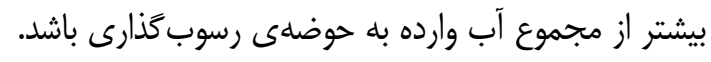

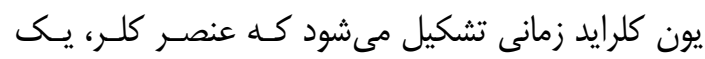

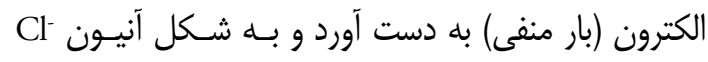

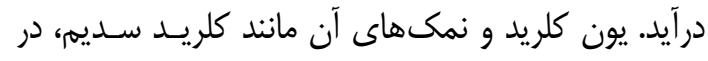

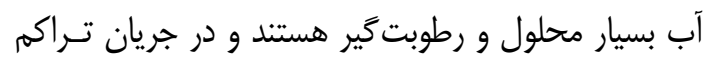

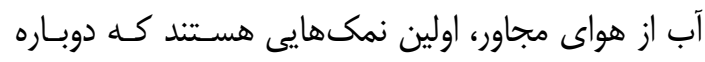

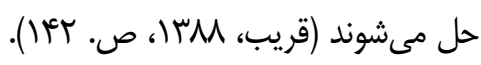

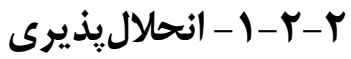

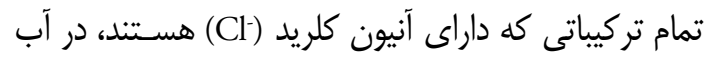

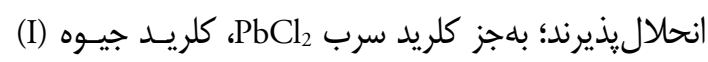
Hg و كلريد نقره AgCl $\mathrm{Hg}_{2}$

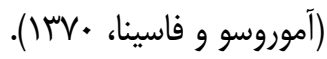

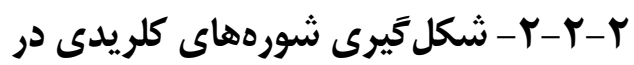

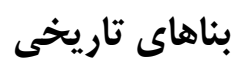
وجود كلريدها در مناطق ساحلى امرى عادى است زئسرا

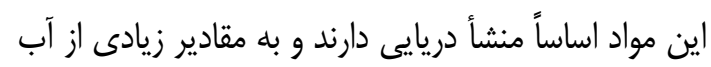

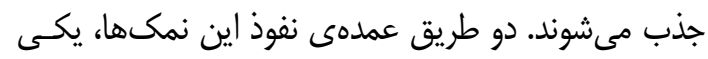

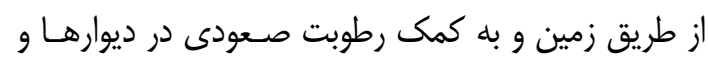
ديكرى از مواد ناخواستهى دريايى است كه توسط بـاد بـ بـهـ
ديوار نفوذ كرده و با كج تركيب مىشود و به سطح ديـوار

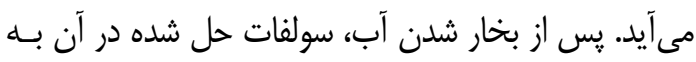

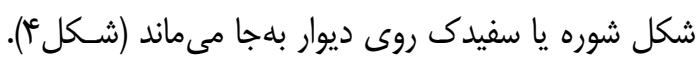

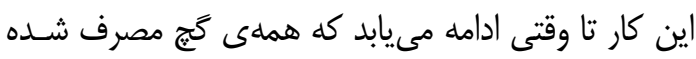

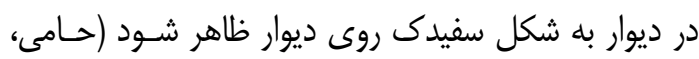

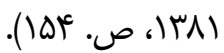

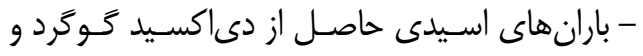

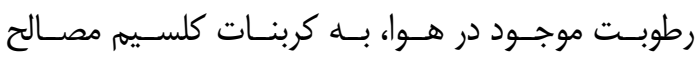

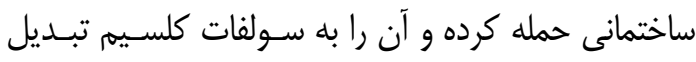

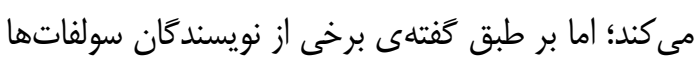

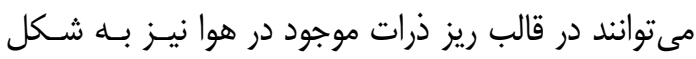
رسوب خشك روى سطوح تلهنشين شوند.

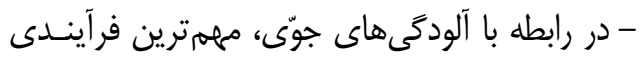

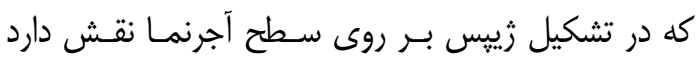
عبارت است از: اكسيداسيون ناهمكن كاز

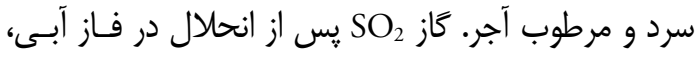

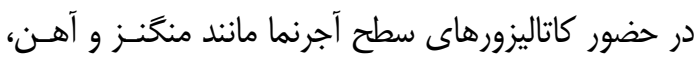

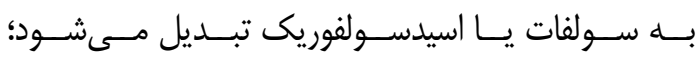

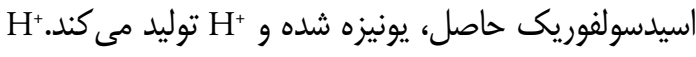

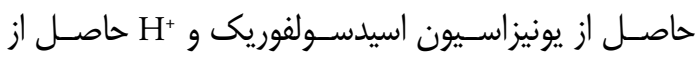

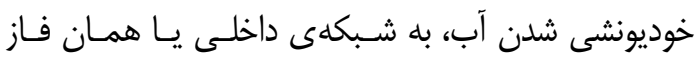

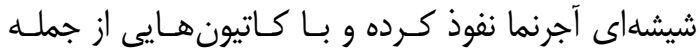

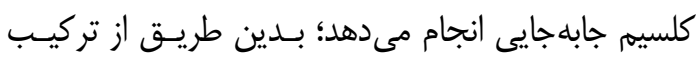

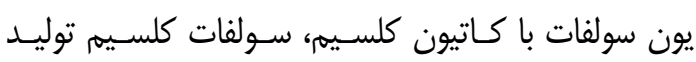

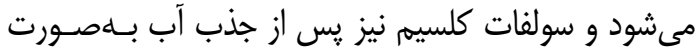

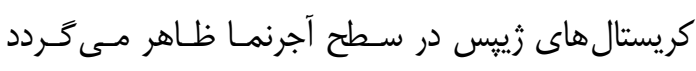

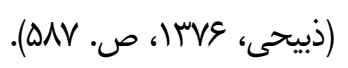
$\mathrm{H}_{2} \mathrm{SO}_{4} \leftrightarrow \mathrm{H}^{+}+\mathrm{HSO}_{4}$ $\mathrm{HSO}_{4} \leftrightarrow \mathrm{H}^{+}+\mathrm{SO}_{4}^{2-}$

يونيز اسيون خودبلهخودى آب ب $\mathrm{Ca}^{+}+2 \mathrm{OH}^{-} \rightarrow \mathrm{Ca}(\mathrm{OH})_{2}$

$\mathrm{SO}_{4}^{2-}+\mathrm{Ca}(\mathrm{OH})_{2} \rightarrow \mathrm{CaSO}_{4}+2 \mathrm{OH}^{-}$ $\mathrm{CaSO}_{4} \stackrel{2 \mathrm{H} 2 \mathrm{O}}{\longrightarrow} \mathrm{CaSO}_{4} \cdot 2 \mathrm{H}_{2} \mathrm{O}$ - شـايعتـرين فـرم از فســاد سـولفاتهـا تشـكيل

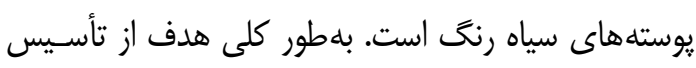

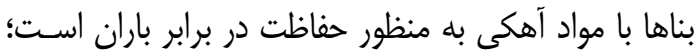


جدول ه: شايعترين كلريدهاى رسوبى (موسوى حرمى، TrVا، ص. •rr).

\begin{tabular}{|c|c|c|c|c|}
\hline فرمول & & & حالت & رده \\
\hline $\mathrm{NaCl}$ & Halite & هاليت & \multirow{2}{*}{ بدون آب } & \multirow{4}{*}{ كلرورها } \\
\hline $\mathrm{KCl}$ & Sylvite & سيلويت & & \\
\hline $\mathrm{MgCl}_{2} .6 \mathrm{H}_{2} \mathrm{O}$ & Bischofite & بيسجافيت & \multirow{2}{*}{ آبدار } & \\
\hline $\mathrm{KMgCl}_{3} .6 \mathrm{H}_{2} \mathrm{O}$ & Carnallite & كارناليت & & \\
\hline
\end{tabular}

كممايه بياشـنـد، در ايـن صـورت ايـن اسـيد بــا سـفيدك

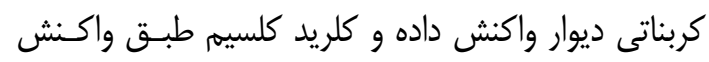

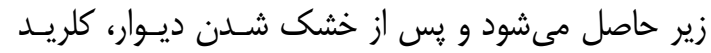

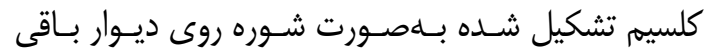

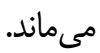

$\mathrm{CaCO}_{3}+2 \mathrm{HCl} \rightarrow \mathrm{CaCl}_{2}+\mathrm{H}_{2} \mathrm{O}+\mathrm{CO}_{2}$ - اكر در ساختن ديوار، ســــ يـا آجـر كلـروردار اسـتفاده

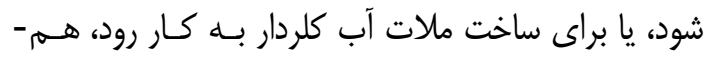

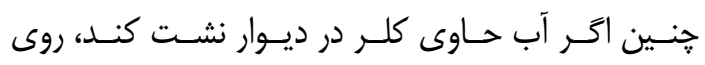

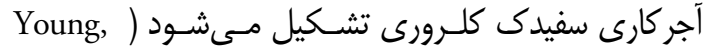

.(2008, p. 13

\section{ت} تخريبِ با شورههاى كلريدى

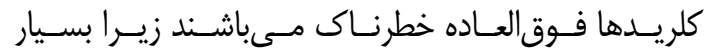
رطوبت گير بوده و ضمن جذب رطوبت اولين نمـكهـايى

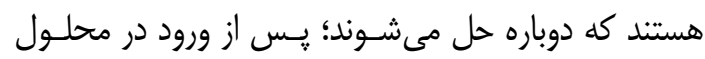
بسيار متحركاند و درنتيجه به درون تخلخلها نفا نفوذ كرده و ساختارهاى بلورى بسيارى را موجب مىشـوند. انحـلال

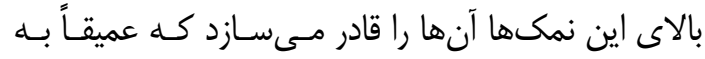
داخل مواد ييشروى كـرده و بــا ايـن نفــوذ تغييراتسى راد در

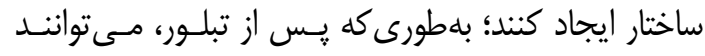

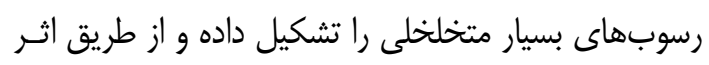

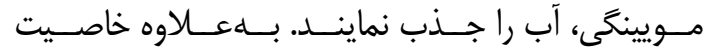

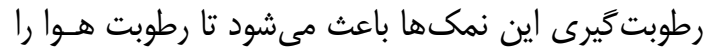
جذب كرده و آن را در درون مصالحى مثل آجر يـا مـلات نغكدارند.

وجود اين نمكها، درجه حرارت لازم جهـت تغييـر

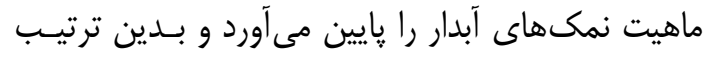

صورت اسبرى دريا حمل شدهانــــ كَاهى اوقـات اسـيد

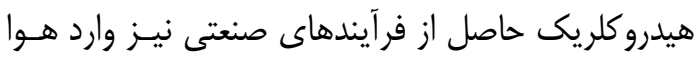

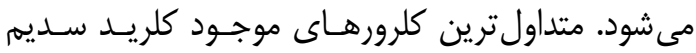
(Halite) (Sylvite)

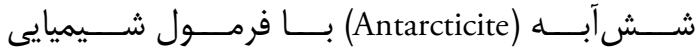

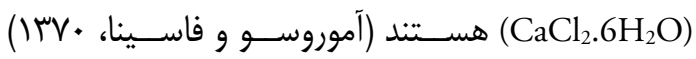

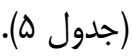

\section{r-Y-T- منشأ كلريدها در بناهاى تاريخى}

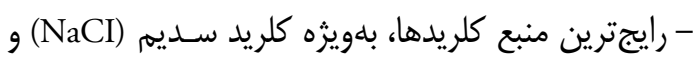
كلريد كلسيم

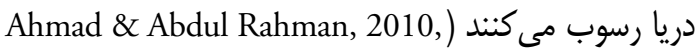
.(p. 94 - كلريدها ممكن است از ناخالصىهاى موجود در مصـالح

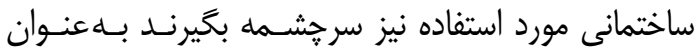

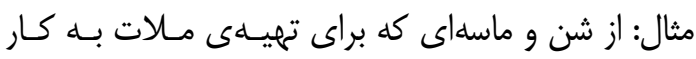
مىروند. -حضور كلريدها هميشه در نزديكى مكـانهـاى استقرار انسانى گستردمى بيشترى دارد، زيرا انسان هـا و حيوانـات ضمن تغذيه، كلريد سديم را دفع مى كنند.

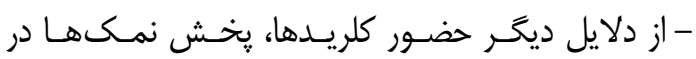
جادهها و راهها بلهنظور يخزدايى در فصل زمستان است.

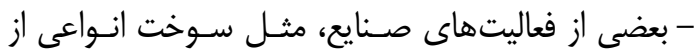

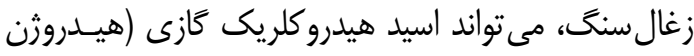

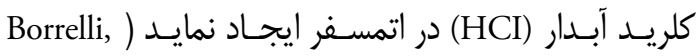

(1999, p. 9

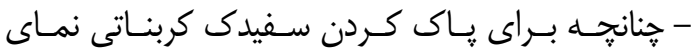

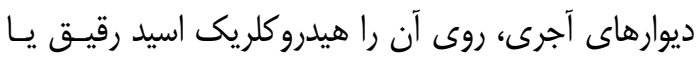


ديوارهى منفذ خواهد شد؛ در مراحل بعدى احـر آبرسـانى دآى دارئ

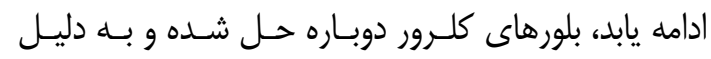
تحرى زيادى كه دارند به نواحى ديخرى منتقل مى شـوند

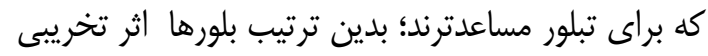

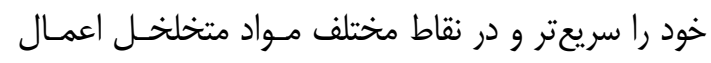

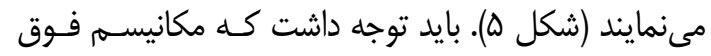

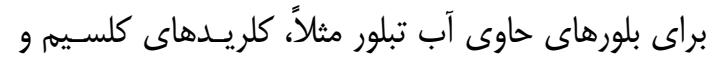

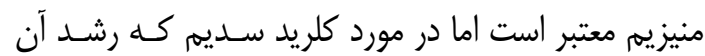

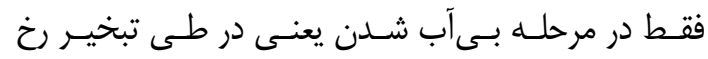

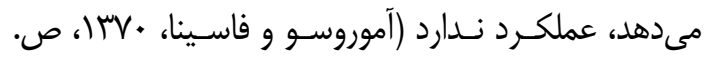

- درصورتى كه بلهنظور پِاكسازى سطوح آجركارى

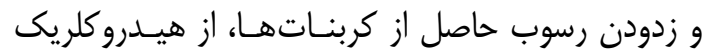

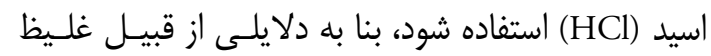

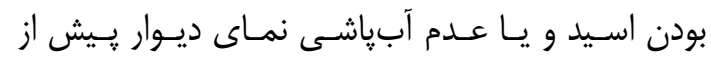

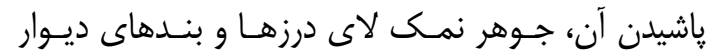

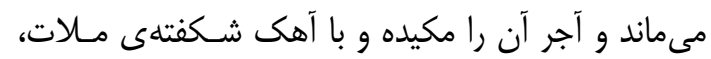

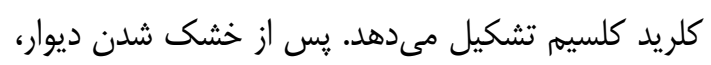
كلريد كلسيم به شكل سفيدك روى ديوار باقى مى مانــــ به دليل اينكه كلريد كلسيه بهشدت رطوبت كايتير است، تـا زمانى كه آب باران آن را از روى ديوار نشويد، در هـواى كـاى

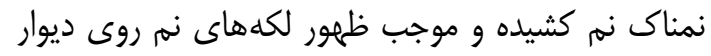

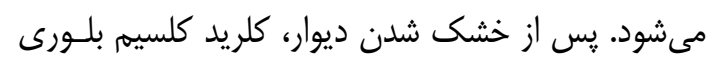

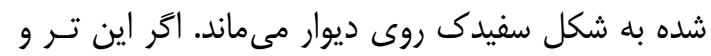

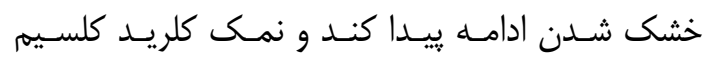

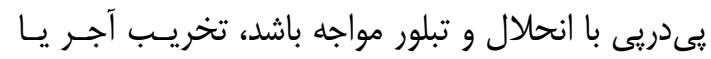

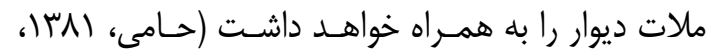

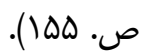

باعث سهولت تغيير ماهيت از يكى حالت آبدار بـه حالـت

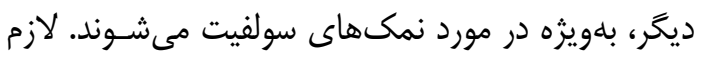
به ذكر است كه حضور نمك كلريد سديم، حلاليت كَّج

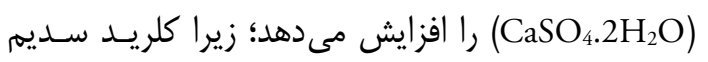

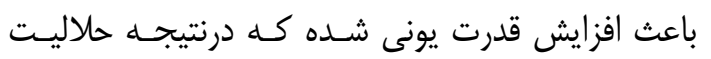

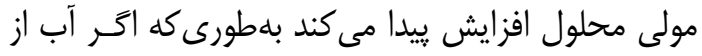

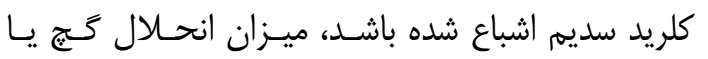

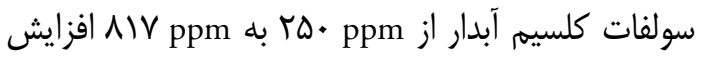

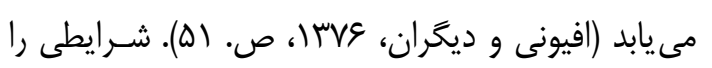

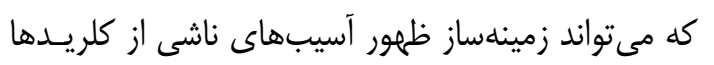
باشد مىتوان به شرح زير بيان نمود:

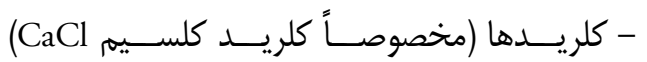

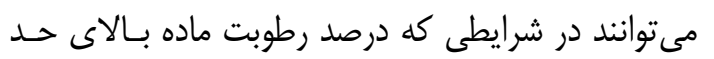

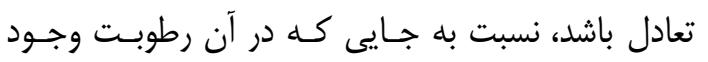
ندارد، تحريك شده و حضور داشته باشند. كلريدها ضمن رطن

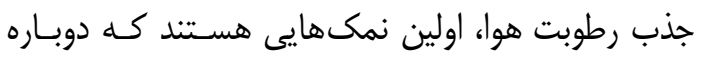

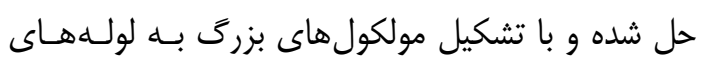
مويين موجود در بافت مواد متخلخل مثل آجر فشار وارد

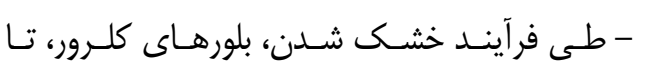

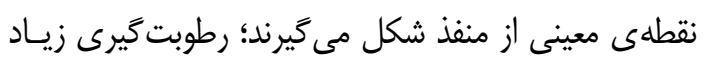

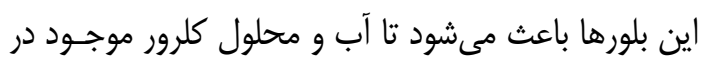

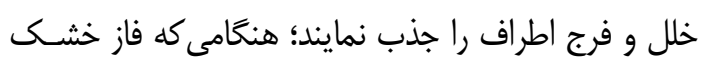

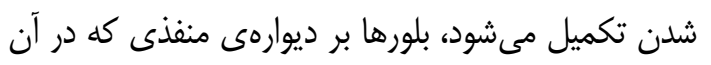

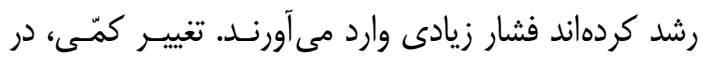

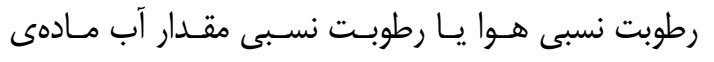

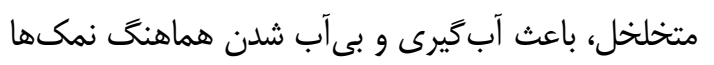

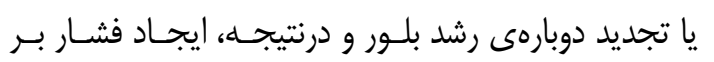
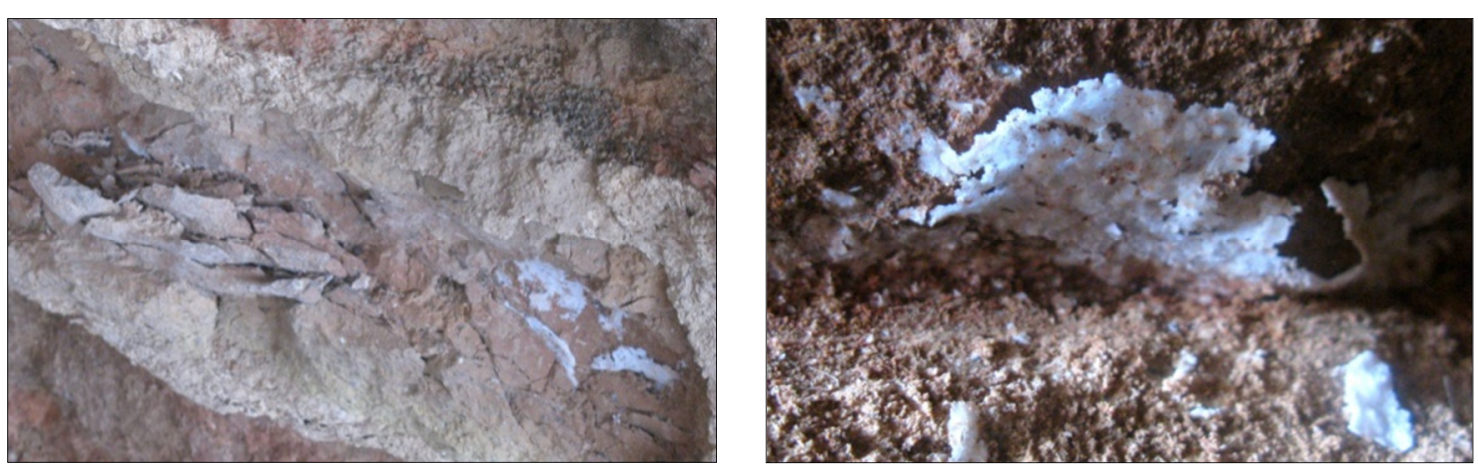

شكل ه: شورههاى حاصل از تبلور كلريدها در سطح آجركارى و تخريب ناشى از آن؛ آرامكاه هفتتبه (يبيرك، بإييز (وسا). 


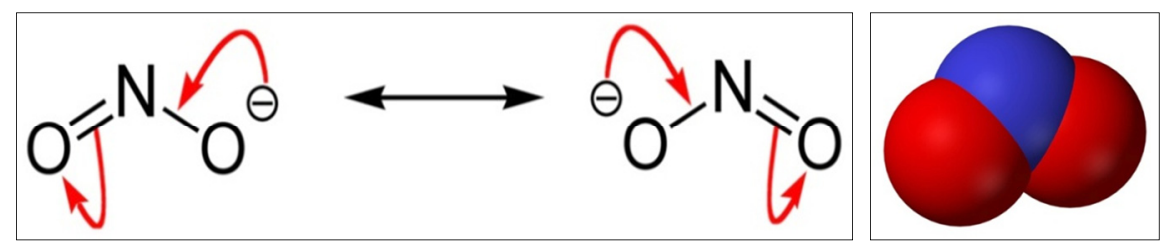

شكل ع. مدل سلبعدى و دو ساختار متعارف از -NO2 كه در ايجاد يبيوند رزونانسى يون نيتريت كمى مى كنند (آموروسو و فاسينا، • (II)).

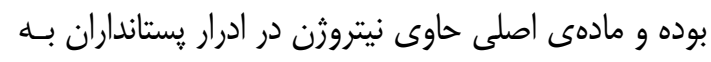

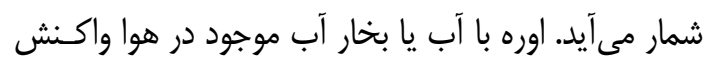
نشان داده و طى آن آمونياك (NH $\mathrm{CO}\left(\mathrm{NH}_{2}\right)_{2}+\mathrm{H}_{2} \mathrm{O} \rightarrow \mathrm{CO}_{2}+2 \mathrm{NH}_{3}$ منابع اصلى آمونياك بلصورت جهار مكانيزيم عبارت

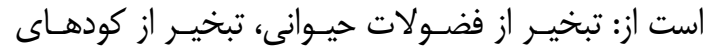

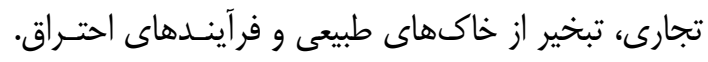

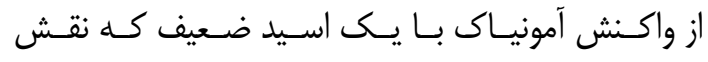

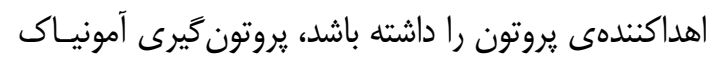

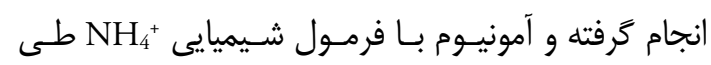
واكنش زير حاصل مىشود. $\mathrm{H}^{+}+\mathrm{NH}_{3} \rightarrow \mathrm{NH}_{4}^{+}$

يون آمونيوم

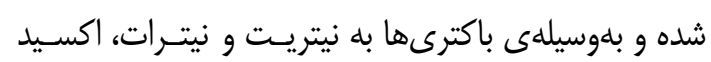
مى كردد. تركيبات نيتريـت و نيتـرات بسـيار محلـول در آب و ودئ

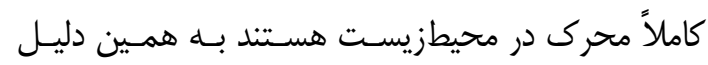

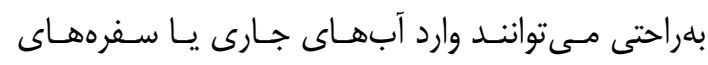

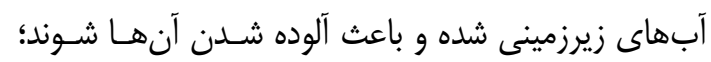

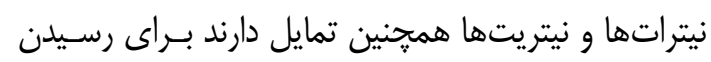

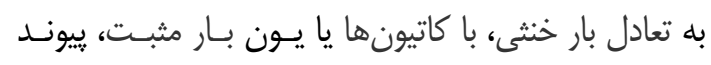

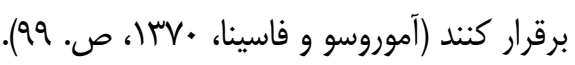

\section{r-r-r-r-r- نيتراتها}

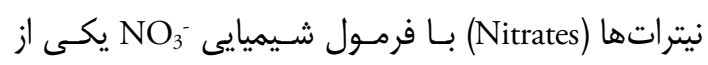

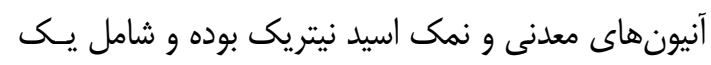

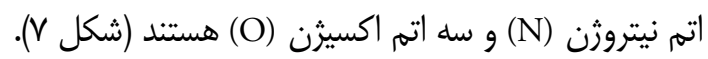

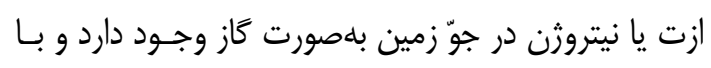

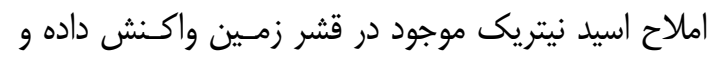

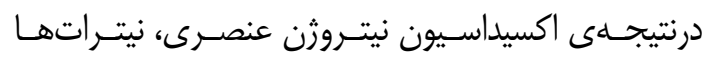
حاصل مىشوند.

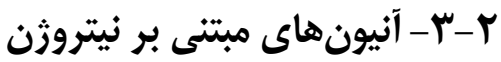

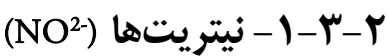

نيتريتها (Nitrites) نمكهاى اسيد نيترو هستند. نيتريـا

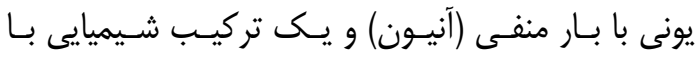

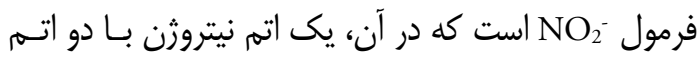

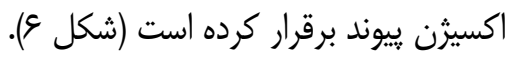

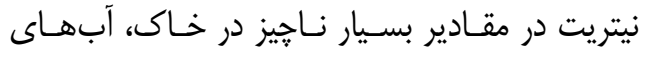

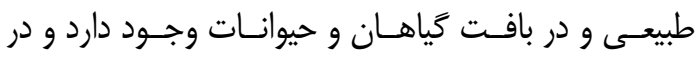

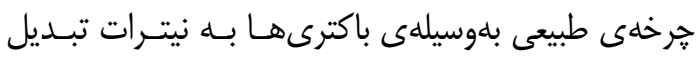

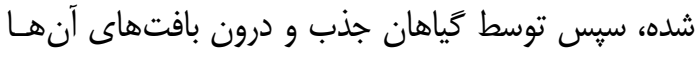

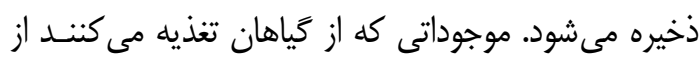

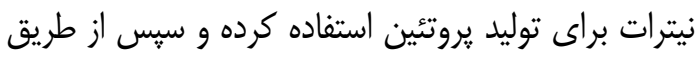

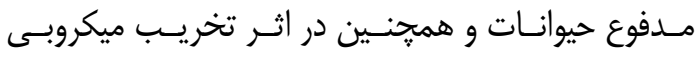

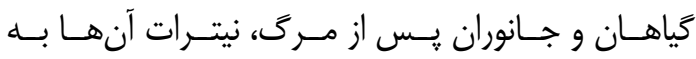

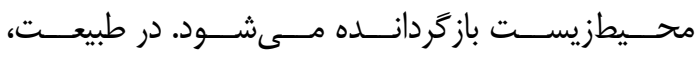

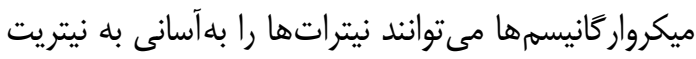

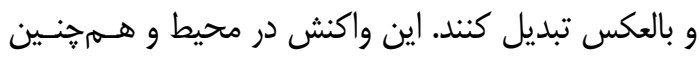
در داخل دستخاه گَوارش انسان و ساير موجودات زنده نيـز

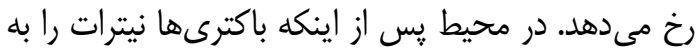

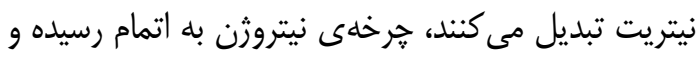

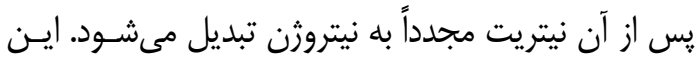

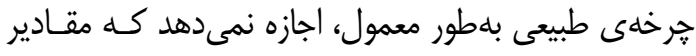

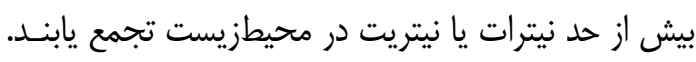

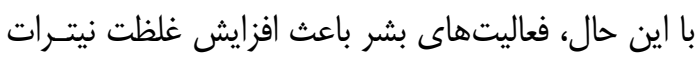

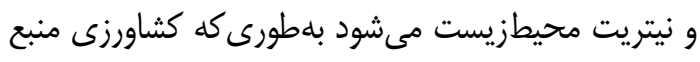

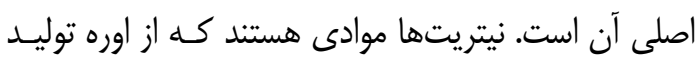

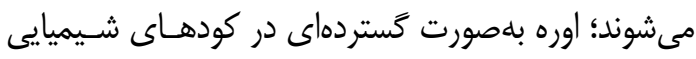

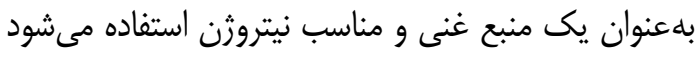

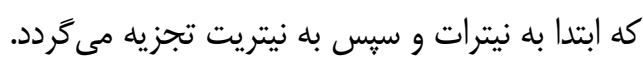
اوره با فرمول شيميايى

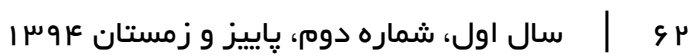



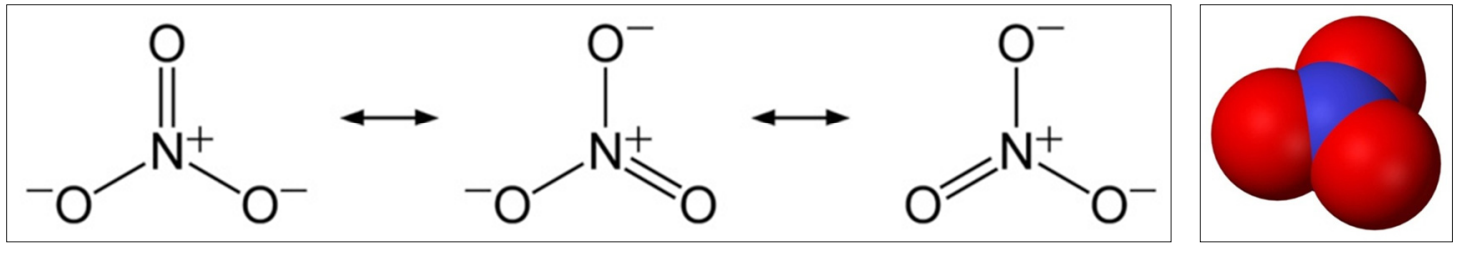

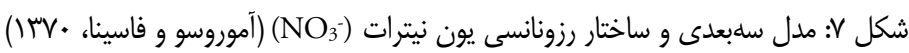

سطحى خاك قادر به حفـظ و نكمهــدارى ايـن دو تركيـب

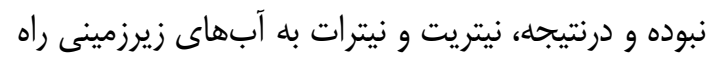
مى يابند. نيتراتهـا در شـرايط هـوازى از اكسـايش نيتـروزن،

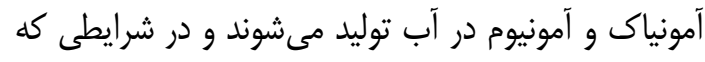
اكسيثن كافى در محيط وجود نداشته باشـد، بـهوسـيلهى ميكرواركانيسمها به نيتروزن كازى (N2) تبديل شـانده و از

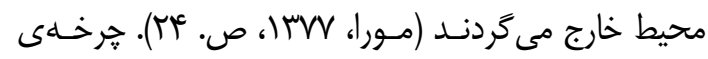
نيتراتسازى در شهرهايى كه دفـع نادرسـت فاضـابلاب از طريق خاههاى جذبى انجام مىشود، همجنان ادامه دارد و

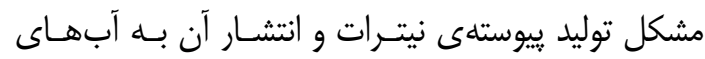
زيرزمينى را سبب مى كردد.

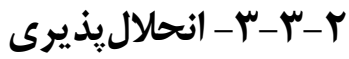

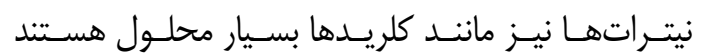
بلهورى كه تمامى تركيباتى كه داراى آنيون نيترات

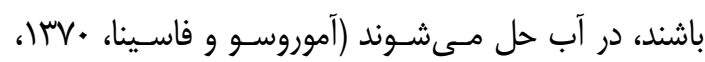

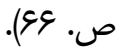

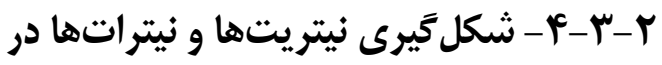 بناهاى تاريخى}

نيتراتها به ميزان كم در بسيارى از شورهها وجـود دارنـــــا.

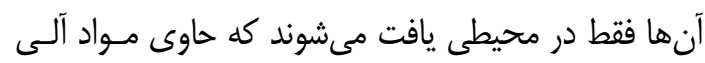

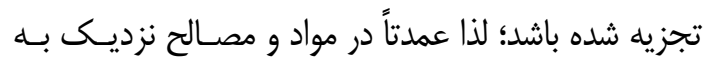

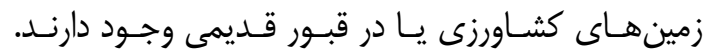

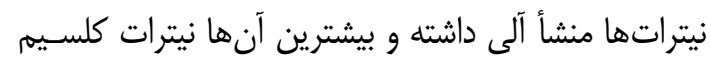

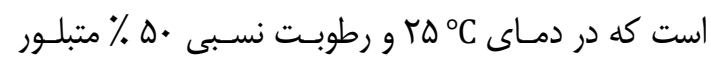

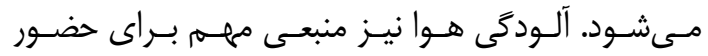

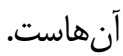
نيتريتها - NO مايل به اكسيد شــن و تبـديل بـــ
نيترات بدون رنخ، بدون بو و بــدون طعهم بـوده و

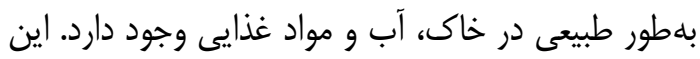
ماده يكى از عناصر بسيار ضرورى براى سنتز يروتئين در كياهان است و نقش مهمى راد در خرخهى نيتروزن دارئ دارد.

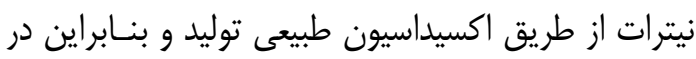
تمام محيطزيست يافت مىشود. به كفتلهى كارشناسان از نظر علمى نيترات محصول نهايى تثبيت هوازى تركيبات

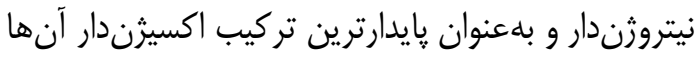
محسوب مىشود كه به مقدار زياد در آب محلول است. از نظر شيميايى ايـن تركيـب واكــش يـــير نبـوده و تنهـا

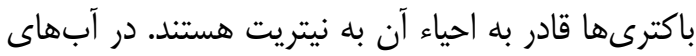

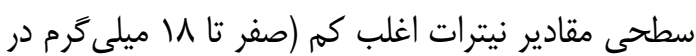
ليتر) و بلمراتب كمتر از آبهاى زيرزمينى است.

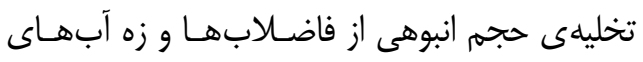

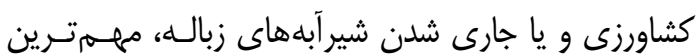
منبع ورود نيترات به آبهاى سطحى محسـوب مسى آشـود

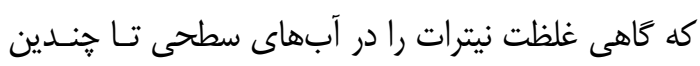

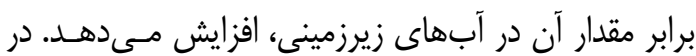
شهرهاى بزرگ، فاضلابهاى شهرى، صنعتى، مواد دفعى

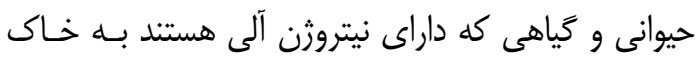

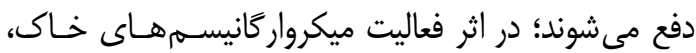
نيتروزن آلى به يون آمونيوم (

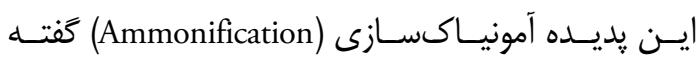
مىشود. خاك توانايى نگَهدارى اين تركيب را در خود دارد

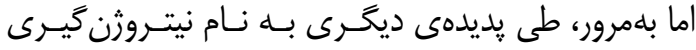

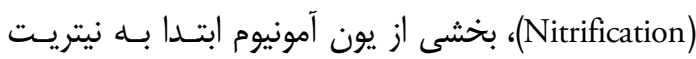
و سِّ به نيترات (NO $\left.\mathrm{NO}_{2}^{-}\right)$

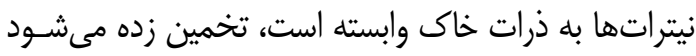

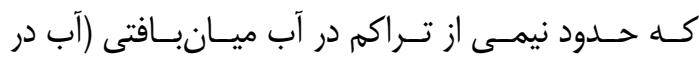

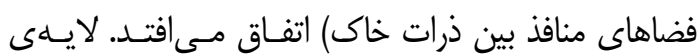


در هواى نمناك نيترات آنهـا آب را جـذب كـرده و روى

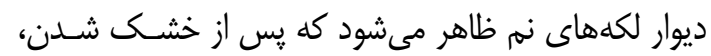

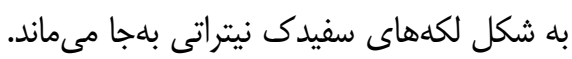

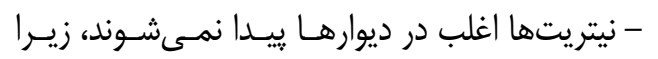

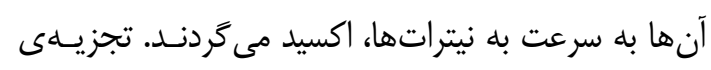

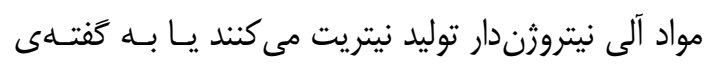

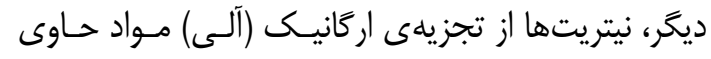

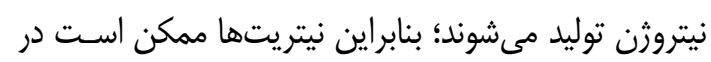

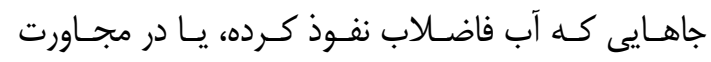

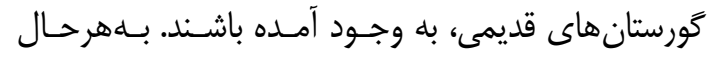
بلهور كلى نيتراتها حضور بيشترى دارند، آنها مى بوتوانند

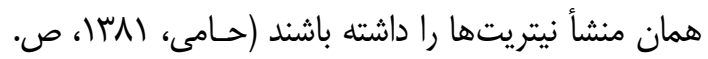

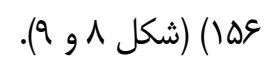

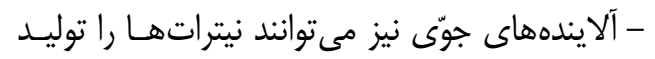

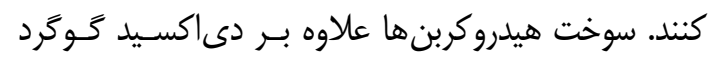

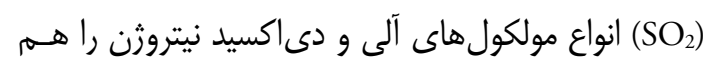

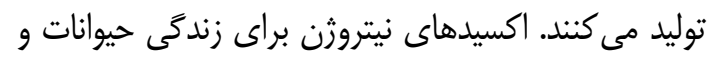

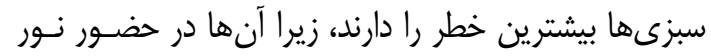

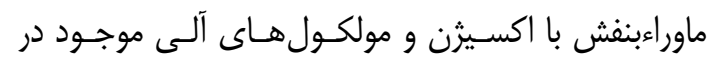

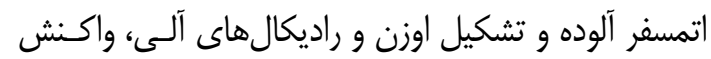

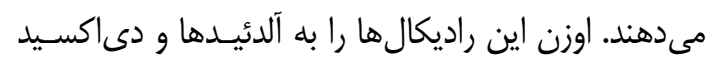

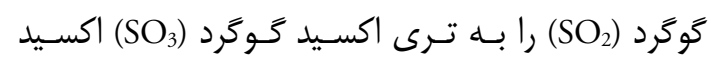

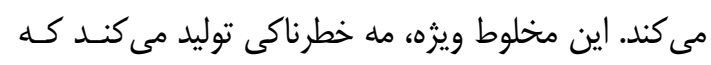

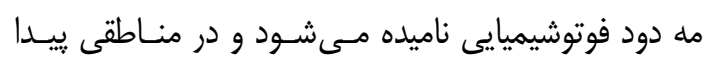

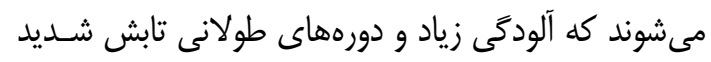

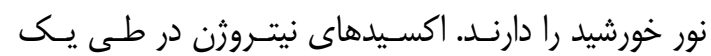

نيتراتها - مO را دارند به همين دليل ييدا كردن آنها در مصالح ساختمانى امرى سخت و دشوار است. متداولترين نيتراتها، نيترات يتاسيم معمولاً منشأ آن آب آلوده است؛ البته ممكن است مقـادير كمى نيترات سديم نيترات كلسيم Ca(NO

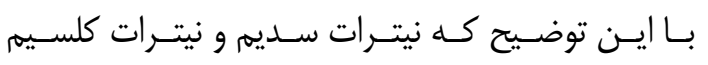

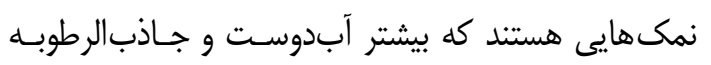

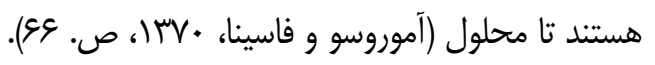

\section{r-ب-ه- منشأ نيتريتها و نيتراتها در بناهاى}

\section{تاريخى} نيتريتها و نيتراتها مىتوانند منشأ مشابهى داشته باشـند

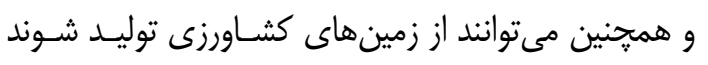

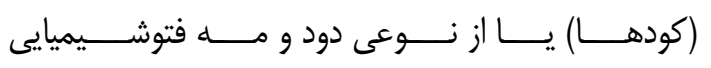

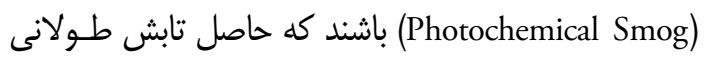

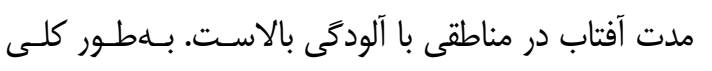

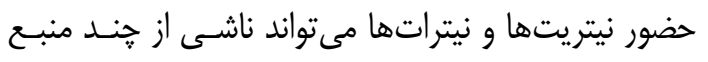
مختلف باشد: - مخور - اكر آجر از خاك شـورهدار سـاخته شــده يـا اجـزاء تشكيل دهندهى مـلات، شـوره داشـته باشـنـ ايـن شـوره

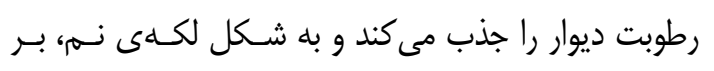

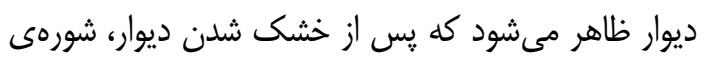
نيتراتى بر روى ديوار يديدار مى گتردد.

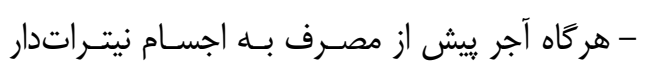

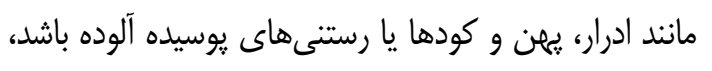

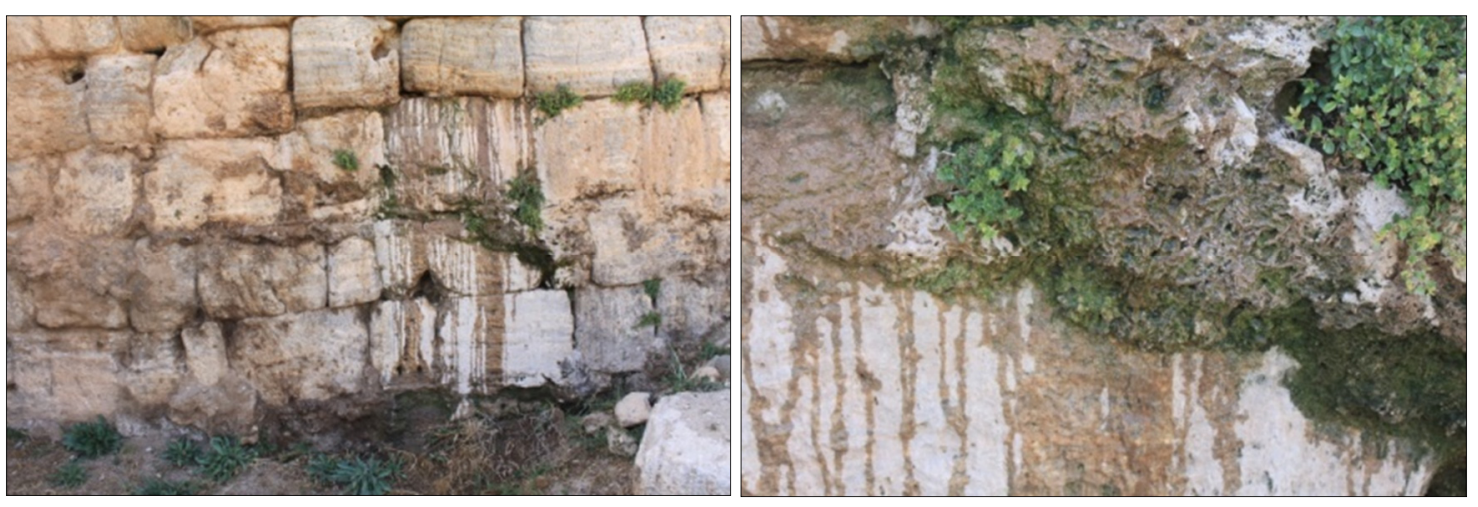

شكل م: نشت فاضلاب سرويس بهداشتى و تشكيل شورههاى نيتراته بر روى سنحَهاى آهكى. باروى شمارهى r مجموعلى جهانى تخت

سليمان. 
ميكروبيولـوزيكى اسـتـ: نيتـروزن و نيتــرو بــاكترىهــا

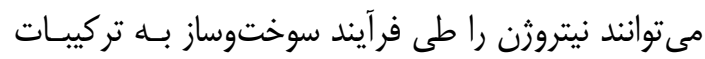

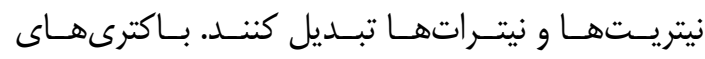
Nitrificant آمونياك را اكسيد كرده و اسيدهاى نيتروزنى را مىسازند كه اين اسيدها توسط بـاكترىهـاى Nitroso

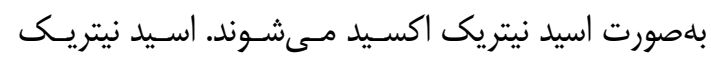

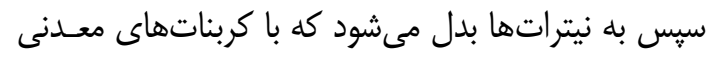

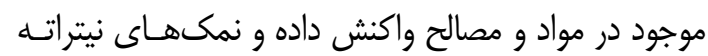

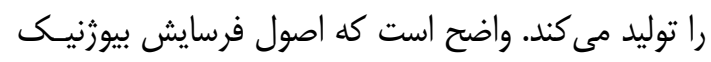

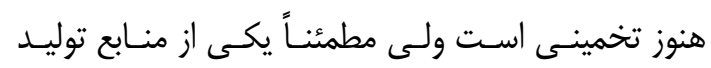

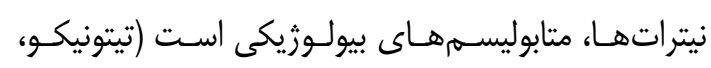

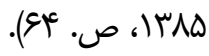

\section{r-ץ-צ-بيش ترين و رايجترين اشكال تخريب نمكهاى نيتريت و نيترات}

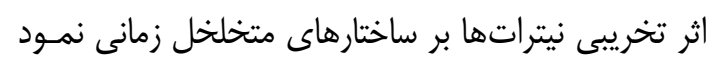

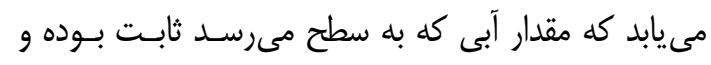

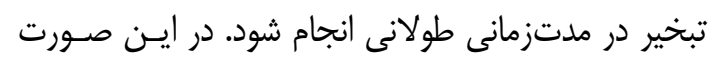

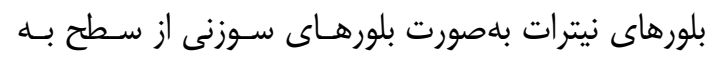

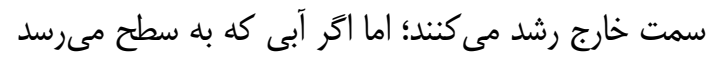

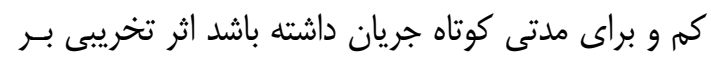

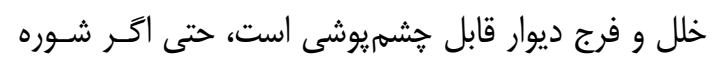

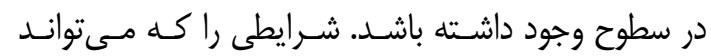
زمينهساز ظهور آسيبهاى ناشى از نيتراتها باشد مى دوتوان به شرح زير بيان نمود:

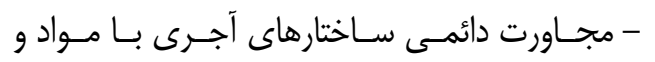

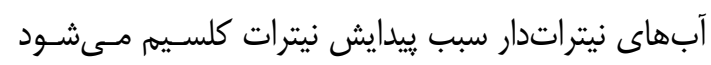

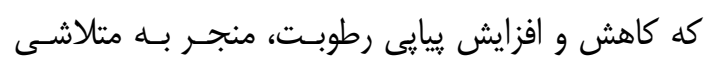
شدن ملاتها و خرابى ساختارهاى يكبار קه مى كردد.

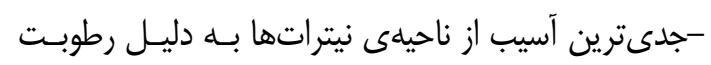

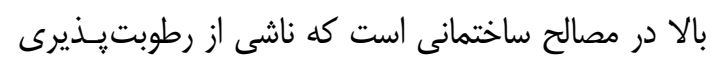

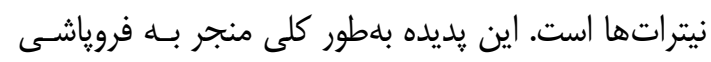

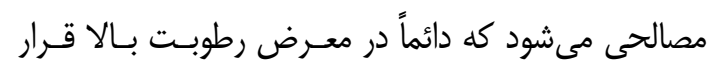
دارند.

- نوع ديخر تغيير، تشكيل فرم اسيد نيتريـك تحـت

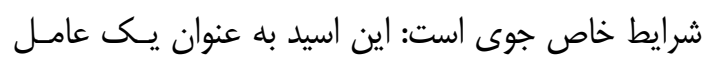

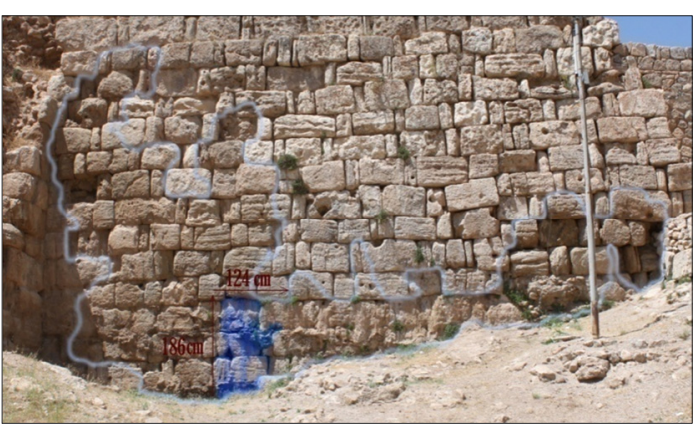

شكل ج: محدودمى افزايش رطوبت ناشى از نشت فاضلاب سرويس

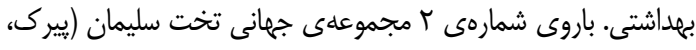

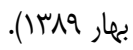

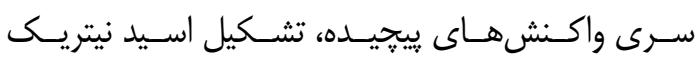

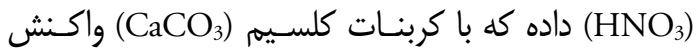

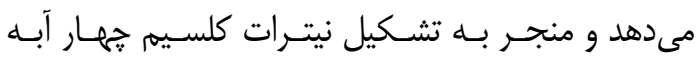

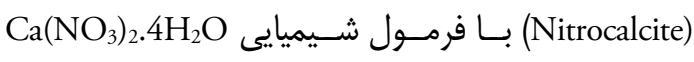

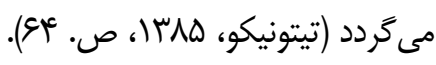

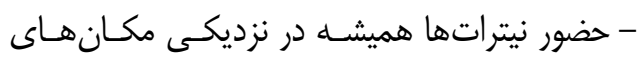

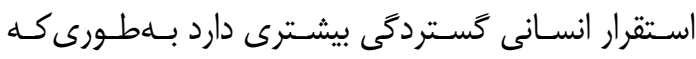

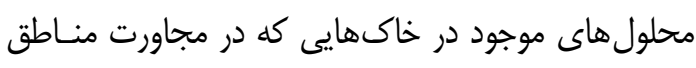

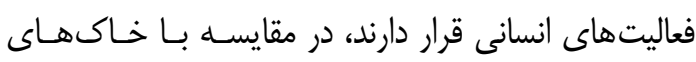

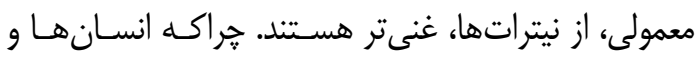

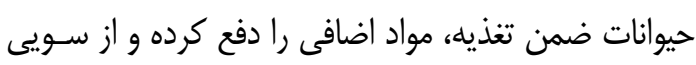

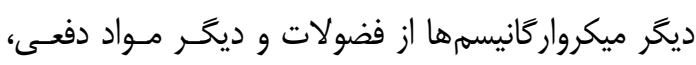

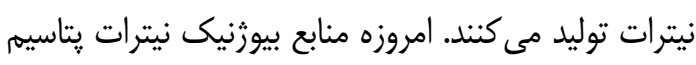

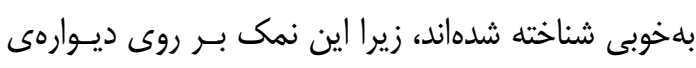

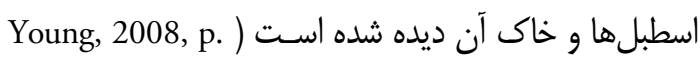

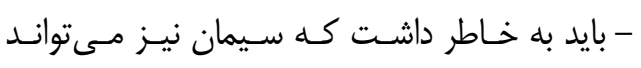
متشكل از جندين نمك قليايى محلول، شامل: سولفاتها،

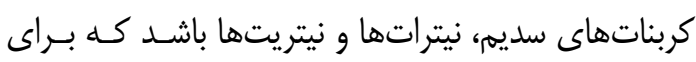

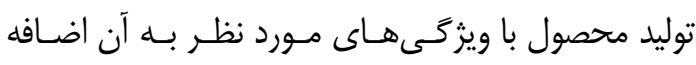
شدهاند. بنابراين اخر ملات سيمان در بناهايى استفاده شود

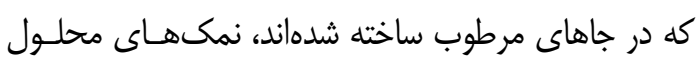

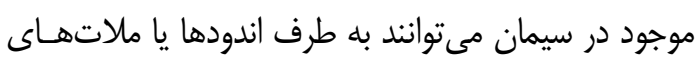

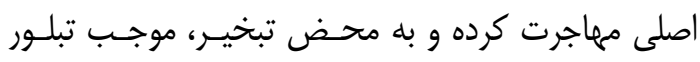
شورههاى مخرب شوند.

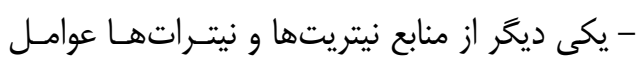




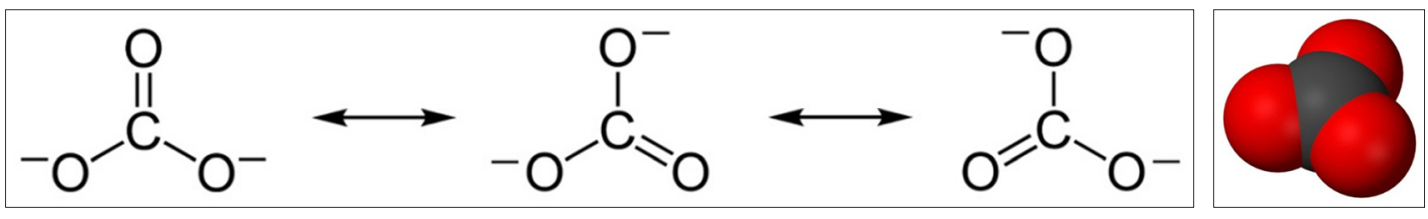

شكل • (: مدل سلبعدى و ساختار رزونانسى يون كربنات (CO $\left.{ }^{2-}\right)$.

از بههم ييوستن كـاتيونهـا بـا آنيـون بـى كربنـات،

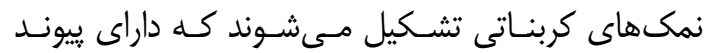

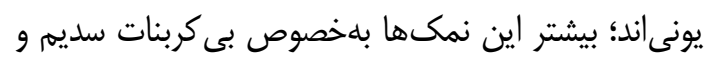

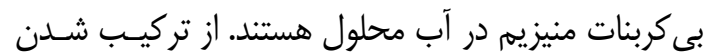

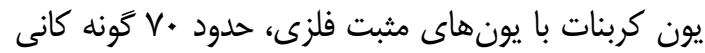

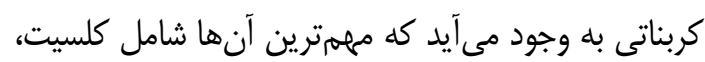
آراكونيت، منيزيت و دولوميت مى باشيد (افيونى و ديخــان،

(I) (I)

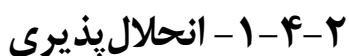

تمام تركيبـاتى كـه داراى آنيـون كربنـات -

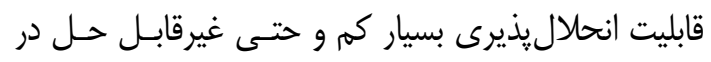

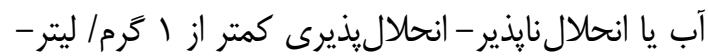

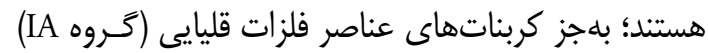

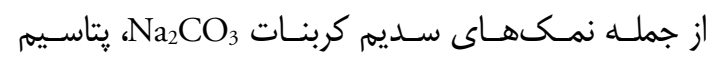
كربنات . $\left(\mathrm{NH}_{4}\right)_{2} \mathrm{CO}_{3}$

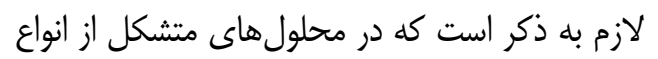
مختلف نمك، ميزان انحلال يذيرى بيشتر نمكهــا تغييـر مى كند بلطورى كه اگر در محيط يون محلول و مشـتركى

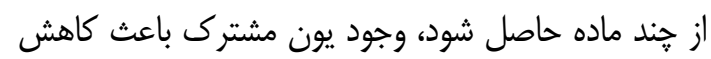

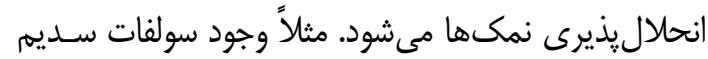
و ولريد سديم NaCl $\mathrm{Na}_{2} \mathrm{SO}_{4}$

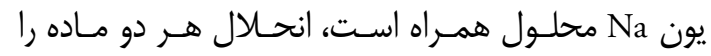

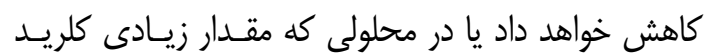

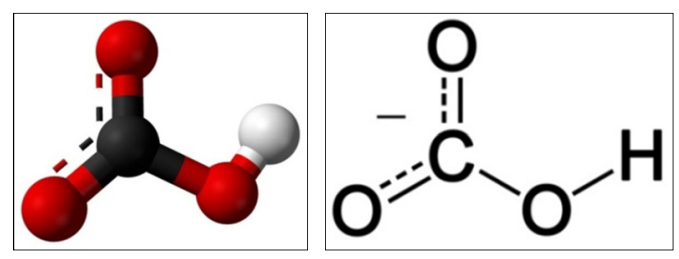

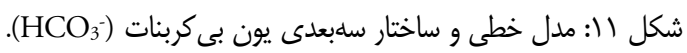

خورنده به آجر و ملات حمله مى كنــــ و همرنــين باعـث

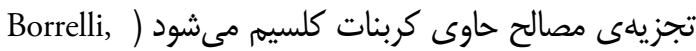

.(1999, p. 7

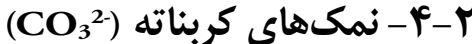

كربنات (Carbonate) يك آنيون جند اتمى با فرمول خـام $\mathrm{H}_{2} \mathrm{CO}_{3} \mathrm{CO}_{3}{ }^{2-}$ است. كربناتها با فرمول عمومى

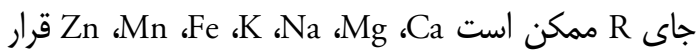
بحيرد. همهى كربناتهـا در HCl

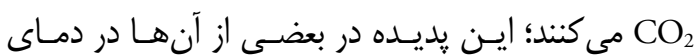

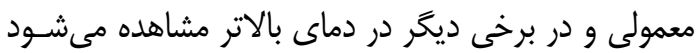

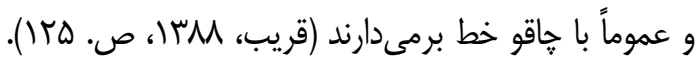

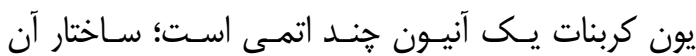

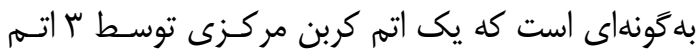

اكسيثن در يك سطح مثلثى احاطه مى شود (شكل • •(1).

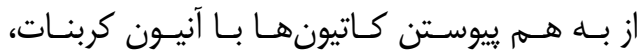

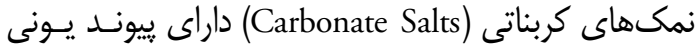

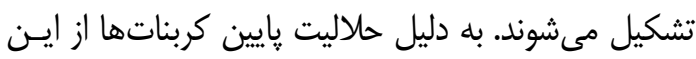

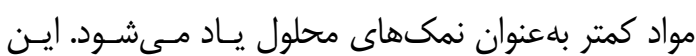

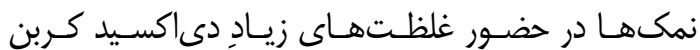

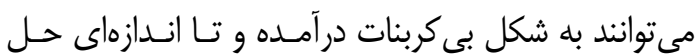

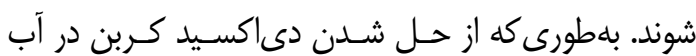
باران، اسيدكربنيك به دسـت مسى آيـد و ايـن اسـيد يـون

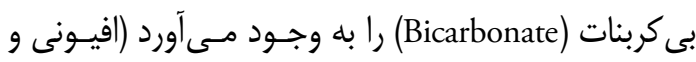

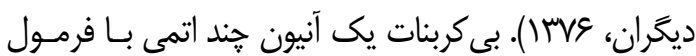

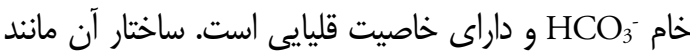

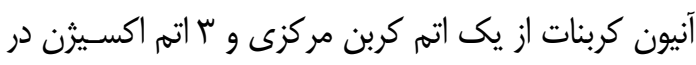
اطراف اتم كربن شكل كرفته كه يكى از اتمهاى اكسـيثن، داراى هيــدروزن نيـز اسـت (شـكل (1). بـى كربنـات بــاز مزدوجى از كربنيك اسيد (Carbonic Acid) است.

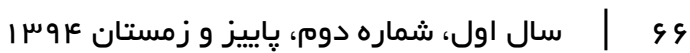




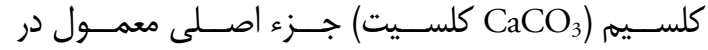

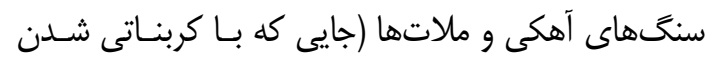

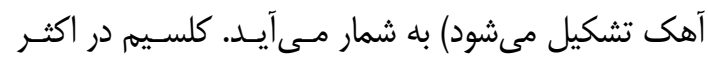

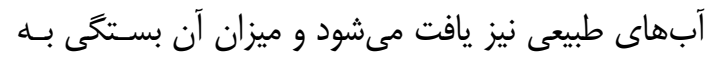

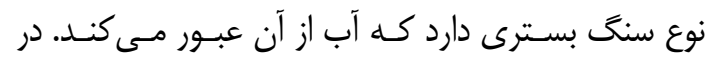

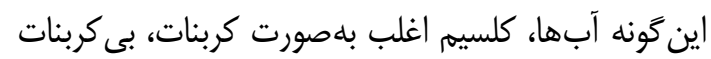
و سولفات ديده مىشود.

- منشأ ديخر كربناتها مىتواند از سيمان بنايى باشد

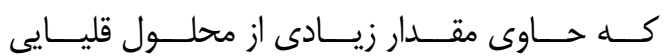
ناترون (Natron) با حلاليت بالا باشـد. $\mathrm{Na}_{2} \mathrm{CO}_{3} .10 \mathrm{H}_{2} \mathrm{O}$ كربنات سديم

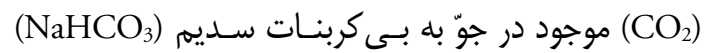

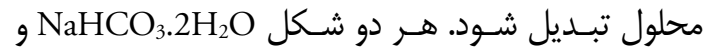

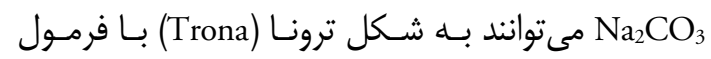

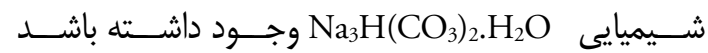
.(Borrelli, 1999, p. 7)

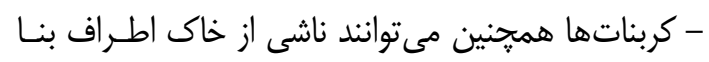

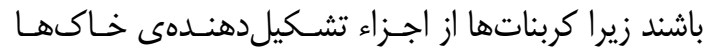

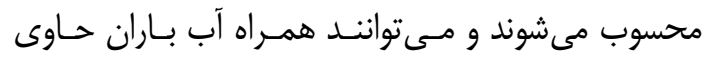

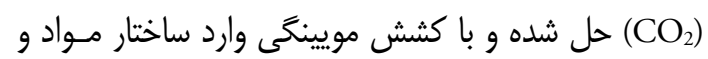

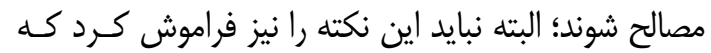

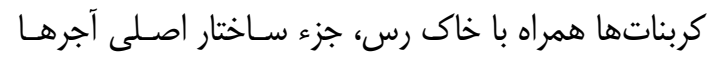

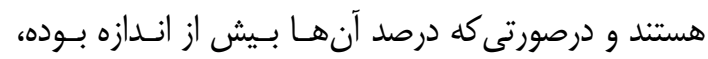
دماى پخت كوره مناسب نباشد و نيز شرايط براى تشكيل

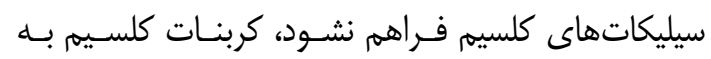

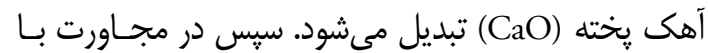

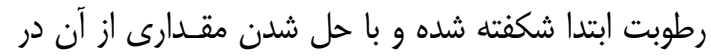

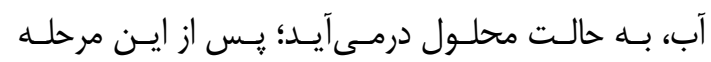

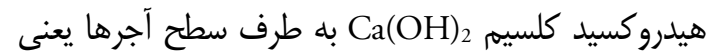

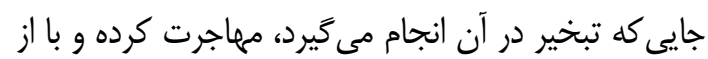

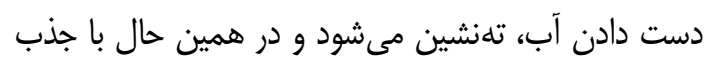
مجدد (CO2) از هوا دوباره به فرم كربنات كلسـيهم تبـديل مى گردد (فروتنى، سגسו، ص. V• (1).

\section{تخ تخريب نمكهاى كربناته} آسيبهاى ناشى از رفتار كربناتهـا مـىتوانـــ در اشـكال

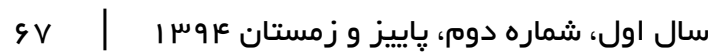

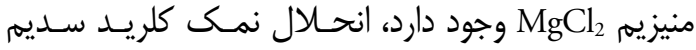

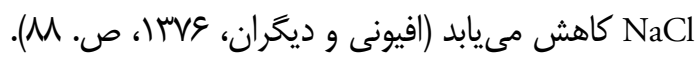

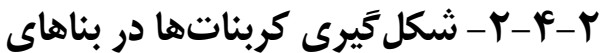

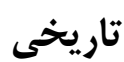

كربناتها، نمكهايى هستند كه تنها بـا حضـور مقـدارى در آب حل مىشوند مانند كربنات كلسـيه $\mathrm{CO}_{2}$ برخلاف ساير نمكهاى شوره، كربنـات كلسـيم عمـالَ در

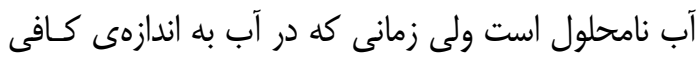

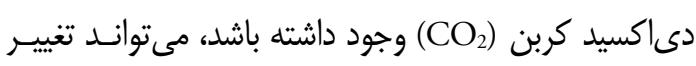
شكل داده و به بى كربنات كله محلول است تبديل شود. دىاكسيد كربن، كازى است كه بـهـطـور معمـول در اتمسفر وجود دارد، اگر دىاكسيد كربن (CO $)$ موجـود در جوّ، بالاتر از حد معمول باشد (تحت شرايط خاص، غلظت دارد

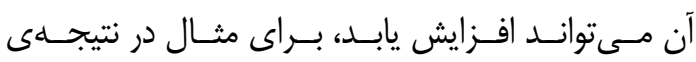

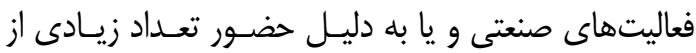
مردم در يك فضاى بسته)، دىاكسيد كربن در آب موجود

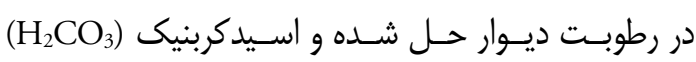

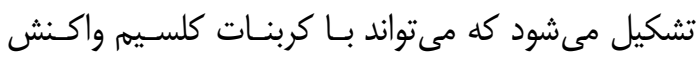

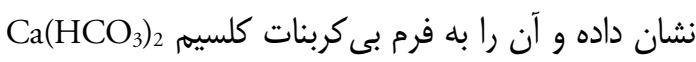

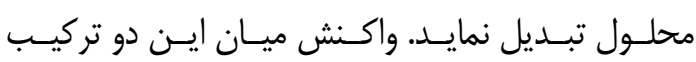
بلهورت زير است:

$2 \mathrm{CaCO}_{3}+\mathrm{H}_{2} \mathrm{O}+\mathrm{CO}_{2} \rightarrow \mathrm{Ca}\left(\mathrm{HCO}_{3}\right)_{2}$ بى كربنات محلول، به سطحى مى آيـد كـه تبخيـر در

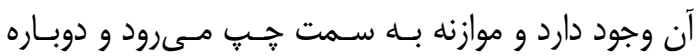
نامحلول شكل مى $\mathrm{CaCO}_{3}$ شده و رسوب مى كند. بهتر است به اين نكته نيز اشـاره داشـته باشـيم كـهـ

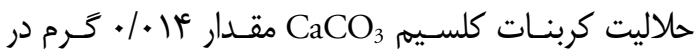
يك ليتر آب است درحالى كه حلاليت بى كربنـات كلسـيم كلئم Ca $\left.\mathrm{CaCO}{ }_{3}\right)_{2}$

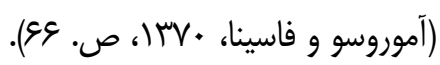

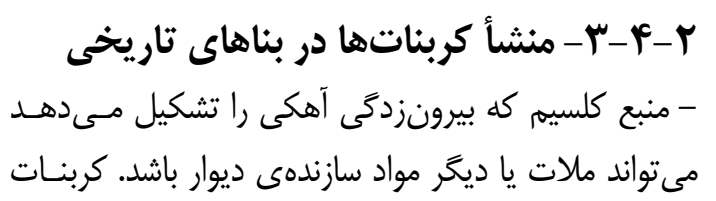
r

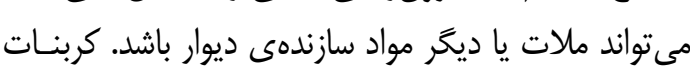



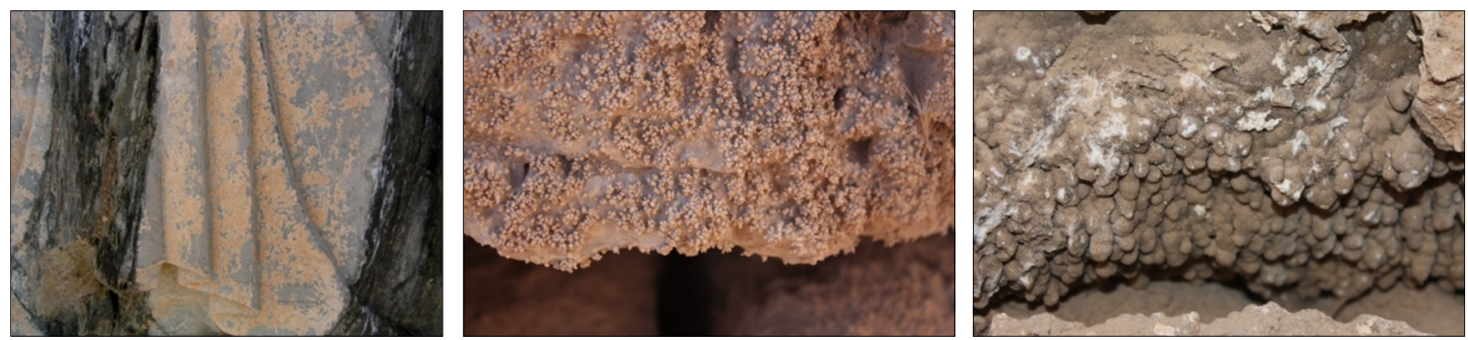

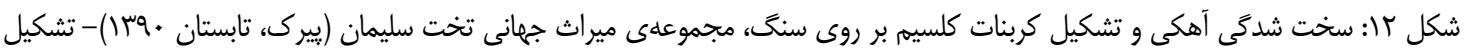

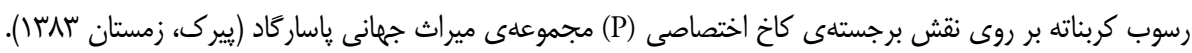

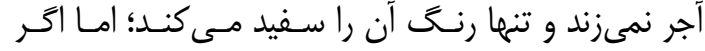

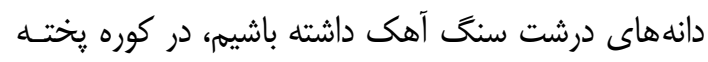

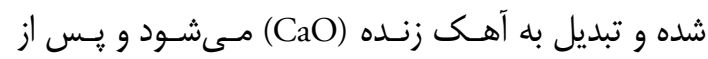

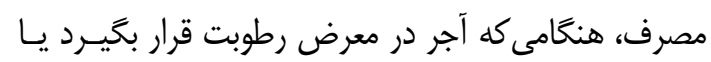

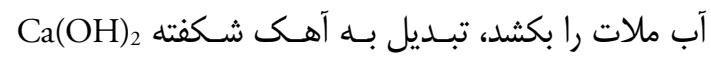

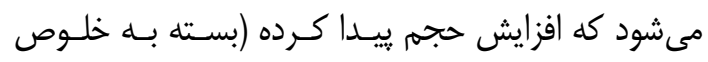

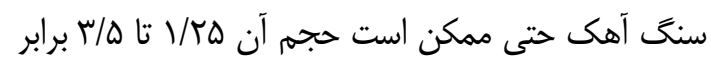

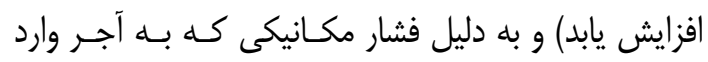

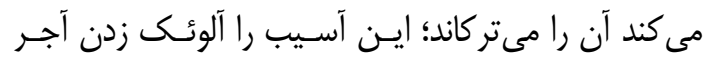

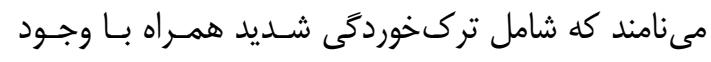

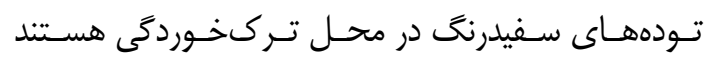

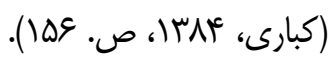
- وقتى دىاكسيد كربن ( باشد، تعادل بين مـواد مختلـف (كربنـاتهـا،

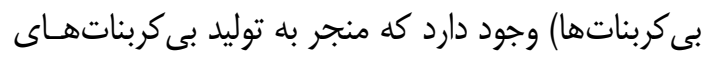

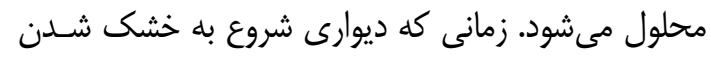

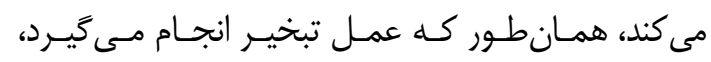

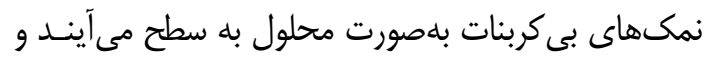

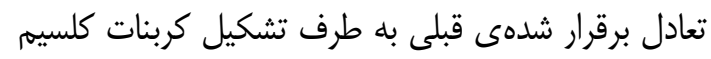

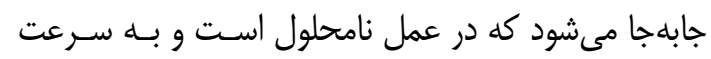

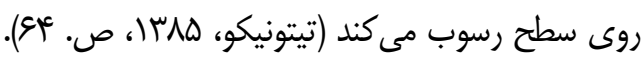

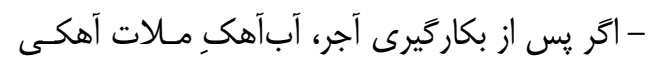
يا سيمانى را بمكد،

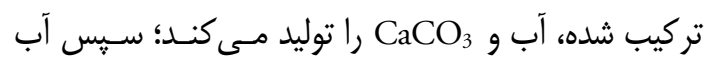
بخار مى شود و

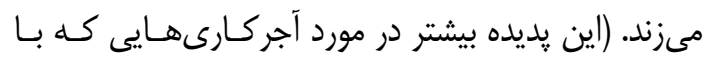

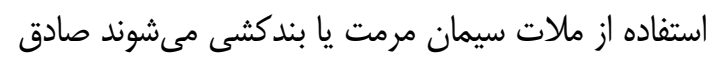

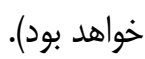

مختلفى ظاهر شده و باعث بدمنظر شدن مـواد و مصـالح كردد و در مراحل ييشرفته، تخريب ساختارهاى يكيارجها

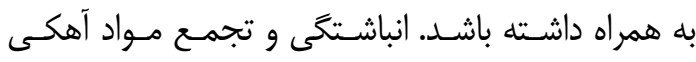

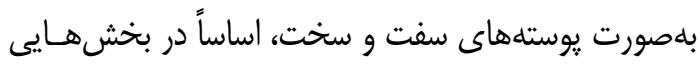
از بنا كه برآمـده هسـتند (جـايى كـه در آن تبلـور اتفــاق مى افتد) ديده مىشود (شكل r r) (1). شكل گَيرى نمكهاى كربناته، فرآيند طبيعى تخريب

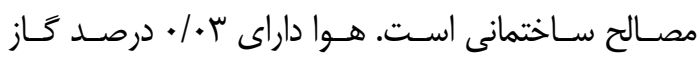

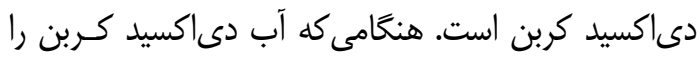

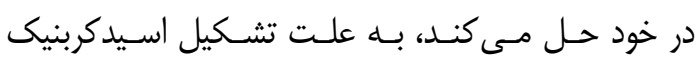

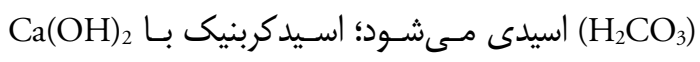

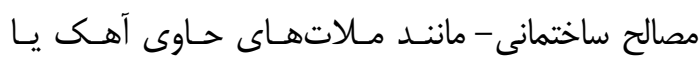
آجرهايى كه در ساختار خود ميزان بالايى اكسـيد كلسـيه دارند كه در حضور آب به هيدروكسيد كلسيم تبديل شدهاند - واكنش داده و

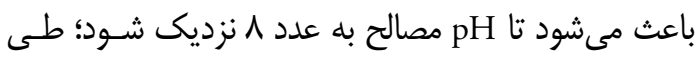
اين فر آيند تقريباً تمامى مىشود.

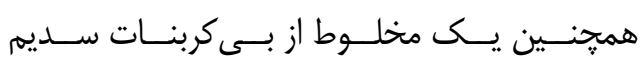

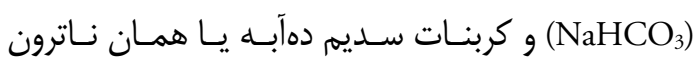

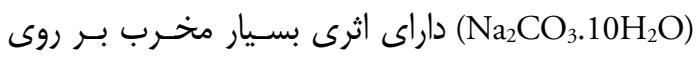
مصالح ساختمانى است.

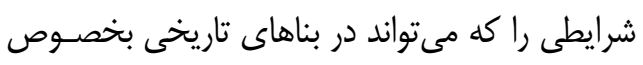

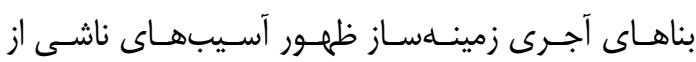
كربناتها باشد مى توان به شرح زين زير بيان نمودي

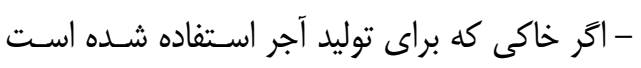
داراى سنگ آهى (CaCO

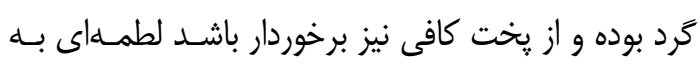

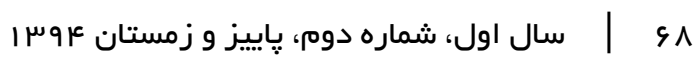


و ا مسىسـازد كـهـ يـس از خــروج $\mathrm{Ca}\left(\mathrm{COCO}_{3}\right)_{2}$ آب، $\mathrm{CaCO}_{3}$

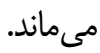
- اين امكان وجود دارد كـه آب، كلسـيم موجـود در مواد و مصالح را به شكل محلول از شكافهاى موجود در

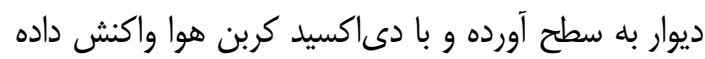
و رسوب يوستهيوستهى كربنات كلسـيم را تشـكيل دهــــ

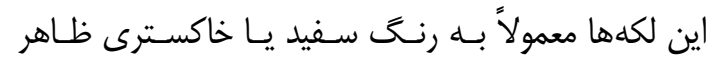

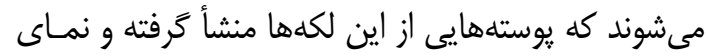

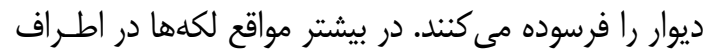

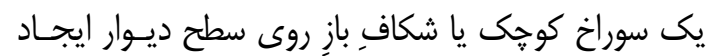

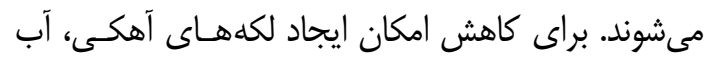

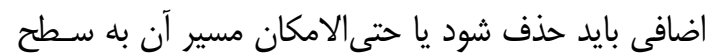

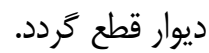
- كاهى اوقات كربناتهاى سديم نيـز بـه دو شـكل آبــار يافت مىشوند. كربنات سديم در درجه حرارتهاى زير

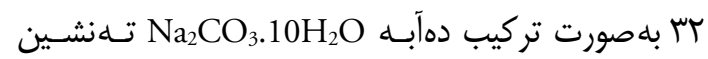

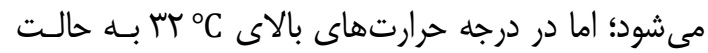

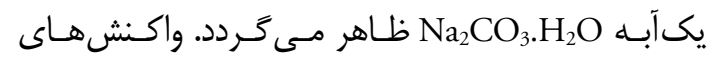
كربنات سديم بسيار شبيه فعل و انفعالات سولفات سـديم است و بدين خاطر مىتوان انتظار اثرات مشابهى را بر آجر داشت (آموروسو و فاسينا، • ل آدا).

\section{r-ه - نمكهاى اتزالاتى}

اگزالاتهـا (Oxalates) بـا نـام آيويـاى (Ethanedioate)

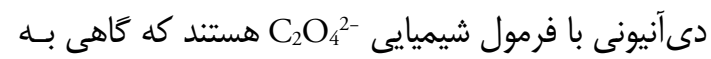
صورت -

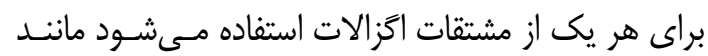

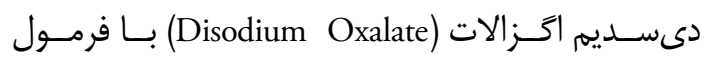
شيميايى $\left.{ }^{2-} \mathrm{Na}^{+}\right)_{2} \mathrm{C}_{2} \mathrm{O}_{4}{ }^{2-}$

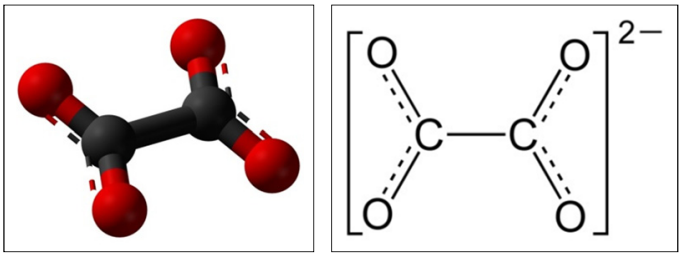

شكل سا: مدل خطى و ساختار سلبعدى يون اخزالات (C)
- زمانى كه آجركارى تازه ساخته شده و اشباع شـده

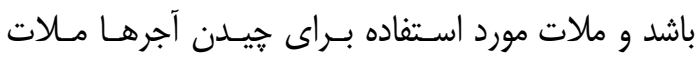

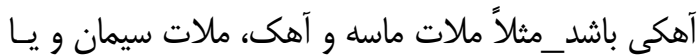

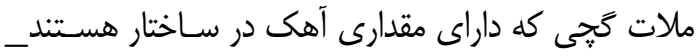

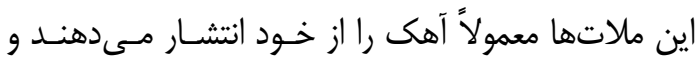
زمانى كه آهك خشك شد لايهاى از هيدروكسيد كلسـيم

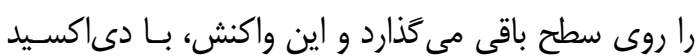
كربن هوا بلهورت كربنات كلسيهم نامحلول درمى آيد.

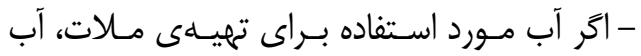

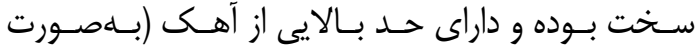

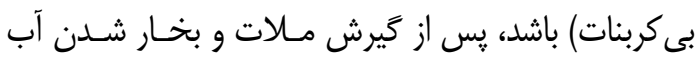

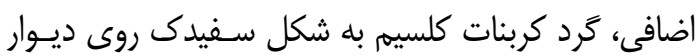
باقى مىماند. دىاكسيد كربن يكى از اجزاء تعادل كربنات

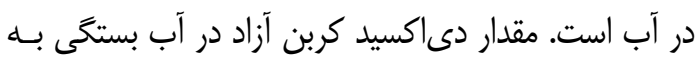

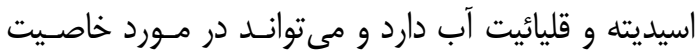

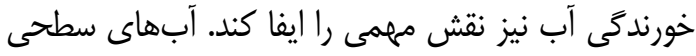

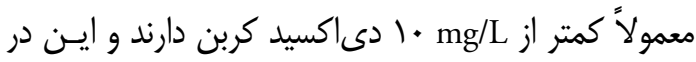
حـالى اسـت كــه در آبهــاى زيرزمينــي عميـق، مقـدار دى اكسيد كربن اغلب بـيش از mg/L +. - اسـت و دليـل

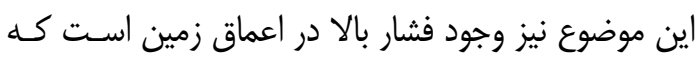
ابتدا باعث افزايش انحلال دى مواكسيد كربن در اين آبهـا شده و در نهايت منجر به انحلال كربناتهاى بيشترى در

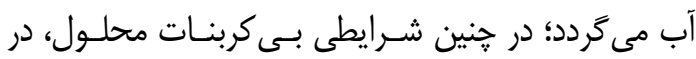

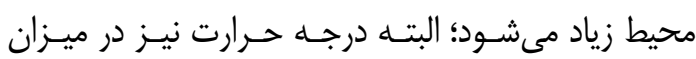

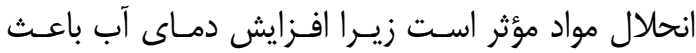
كاهش حل شدن دىاكسيد كربن شده و ميـزان انحـلال آن را در درجه حرارتهاى نزديك نقطهى انجمـاد تقريبـاً

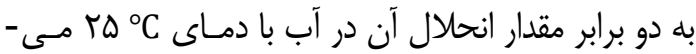
رساند. افزايش فشار موضعى CO جوّى نيز مقدار انحلال

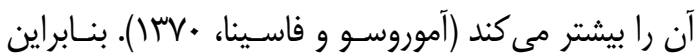
ميزان انحلال كربناتها در فصلهاى سرد سال به دليـل

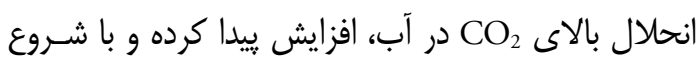

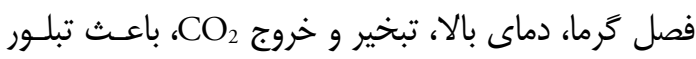

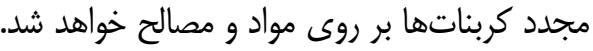

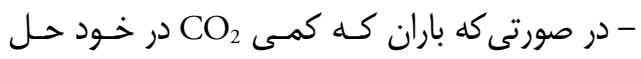
كرده است در ديوار (بلويزه ديوار تازه ساخته شـده) نشـت بـارن كند، با كربنات كلسيه باقىمانده در ديوار تركيـب شــده و

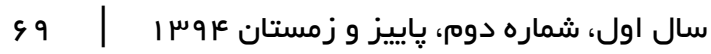


مى كند مانند وولّيـت (Whewellite) بـا فرمـول شـيميايى و ودليـت (Weddellite) ( $\left(\mathrm{CaC}_{2} \mathrm{O}_{4} \cdot \mathrm{H}_{2} \mathrm{O}\right)$ شيميايى $\left(\mathrm{CaC}_{2} \mathrm{O}_{4} \cdot 2 \mathrm{H}_{2} \mathrm{O}\right)$ هستند. - تازهترين فرضيات مطرح شده در مورد شكل ماكيرى اكزالاتها، به حضور منواكسيد كربن (CO) موجود در هوا

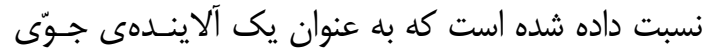

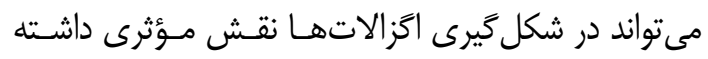
باشد (Borrelli, 1999).

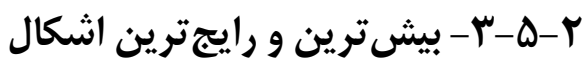 تخريب نمكهاى اتَزالاتى}

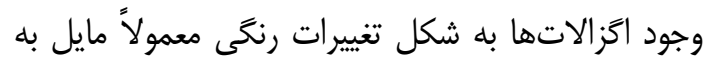
زرد، مايل به قرمز يا مايل به قهوهاى ظاهر مى شودي؛ هاتين تشكيل شده به نوع ناخالصىهاى موجود بستخى دارد.

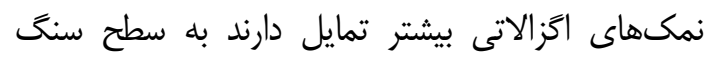
بجسبند. برخى از محققين و نويسندكان عقيده دارند كه

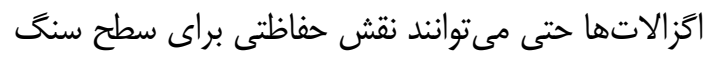

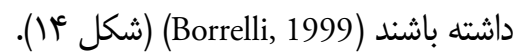

ب-9- نمكهاى فسفاته (-9) فسفاتها (Phosphates) تركيبى غيــر آلى و نمـك اسـيد

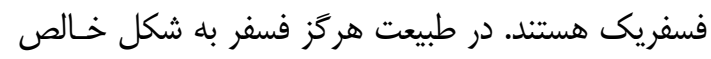
ديده نشده است اما تنها به شكل فسفات ظاهر مسىشـود.

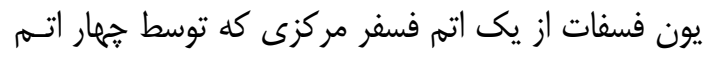
اكسـيزن در يــ آرايـش جهارضـلعى قـرار دارد (-
مانند دىمتيل اخـزالات (Dimethyl Oxalate) بـا فرمـول شيميايى OX

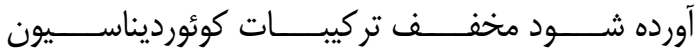

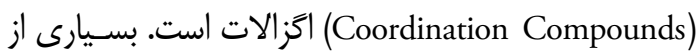

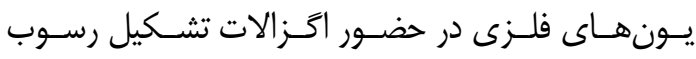

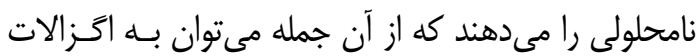

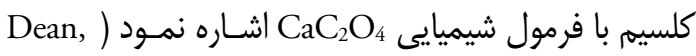
.(2011, p. 417

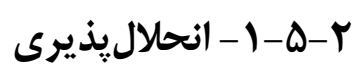

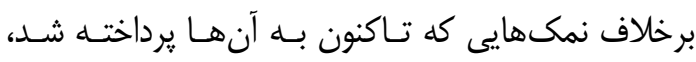

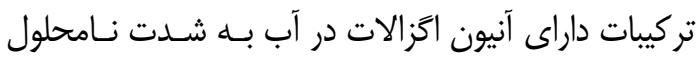

هستند.

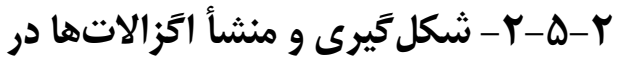 بناهاى تاريخى}

در ميان مكانيسمهاى گَوناگون ييشنهادشده، براى تشكيل

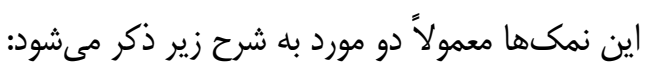

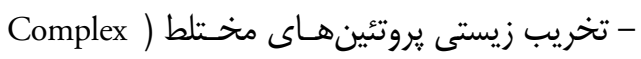
Proteins

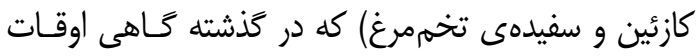

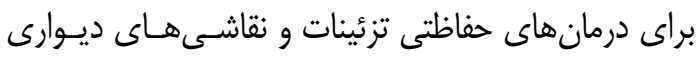

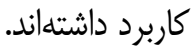

- حضور اسيد اكزاليك كلسنگ ها، در سطح كلسيت واكنش نشان داده و اگزالات كلسيم CaC2
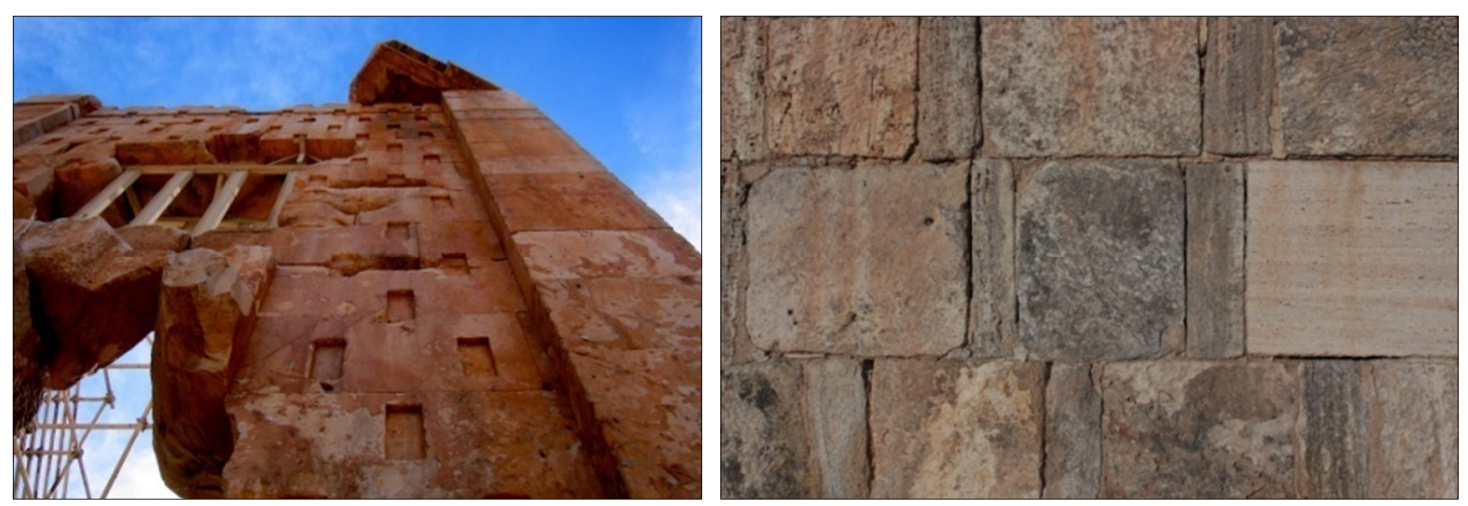

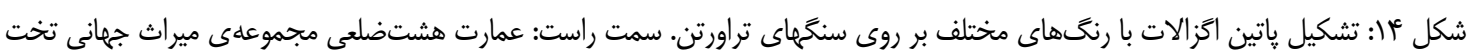

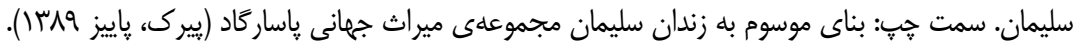


معدنى واكنش داده و ايجاد خـوردخى مسى كنـــ. رسـوبات

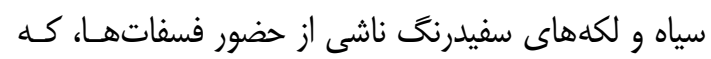

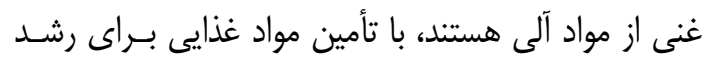

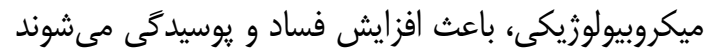

.(Borrelli, 1999, p. 8) همان كونه كه كَفته شد، نمكنهاى فسفاتهى محلـول

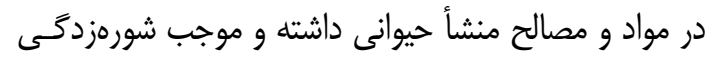

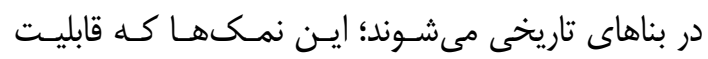

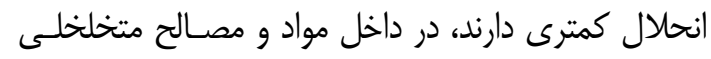

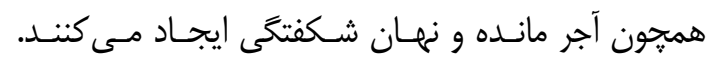

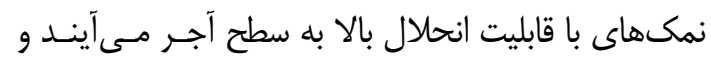

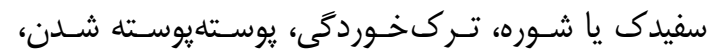

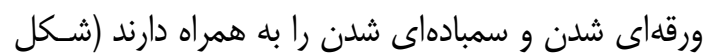

\section{ץ- - جمعبندى و نتيجلكيرى}

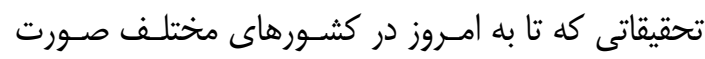

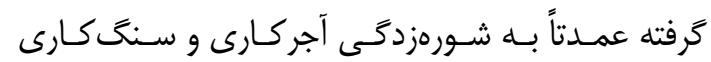

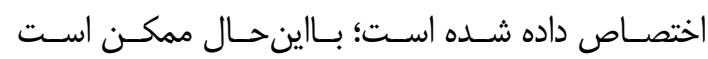
نمكسهاى محلول، روى سطح و داخل مصالح ديخر، مانند

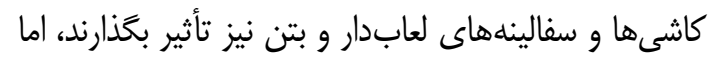

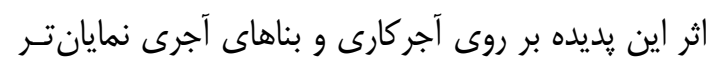

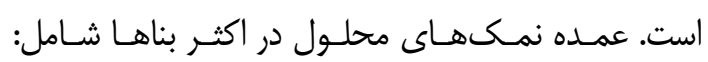

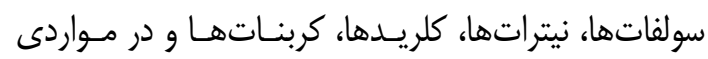

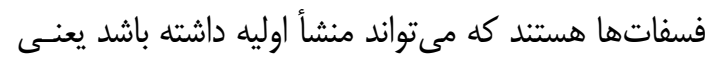
از زمان توليد در داخل مواد و مصالح حضور داشـته باشـند يا اينكه بلطور ثانويه و از منابع خارجى حاصل كر دردند. دانستن مقدار نمك مخـرب سـطح و نمـا، بررسـى علـل كلـ

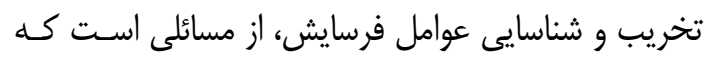

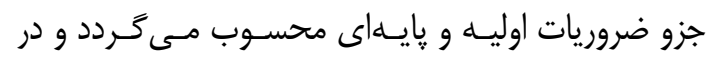

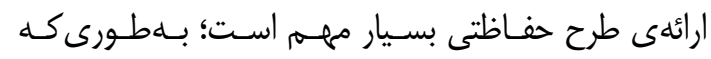

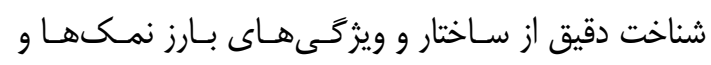

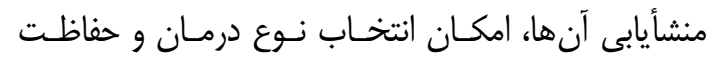
مناسب را تحقق خواهد بخشيد. محل، شكل ظاهرى و آسيبهاى وارده بـهـوسـيلهى

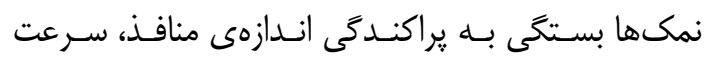

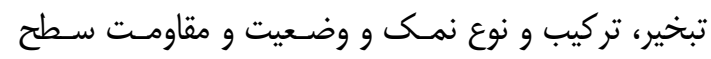

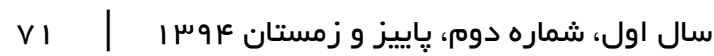

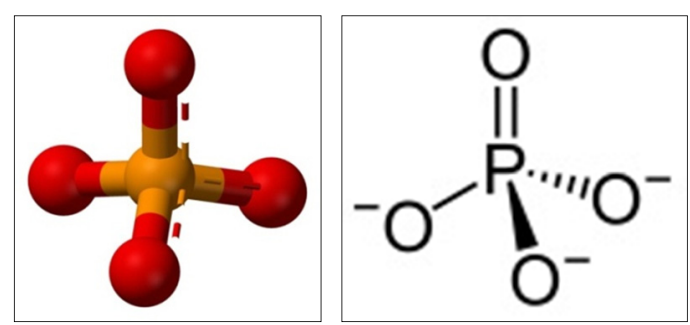

شكل ها: ساختار مولكولى و مدل سلبعدى يون فسفات (POت (PO).

$$
\text { تشكيل شده است (شكل ه ا). }
$$

فسفات شـكل طبيعى عنصـر فسـفر اسـت كـه در

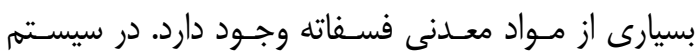

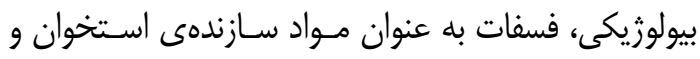
دندان شناخته شده است. در زمينشناسى و كـانى شناسـى

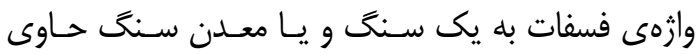

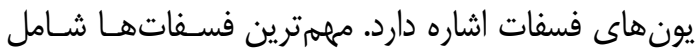

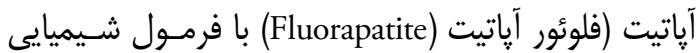
و كلـور آيانيـت (Cas $\mathrm{Ca}_{5}\left[\mathrm{PO}_{4}\right]_{3} \mathrm{~F}$ شيميايى

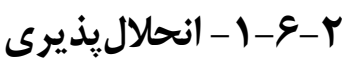

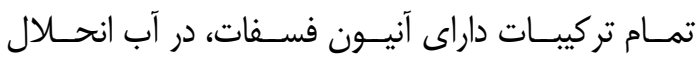

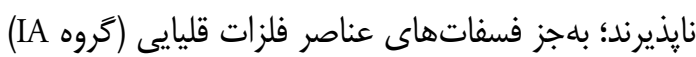

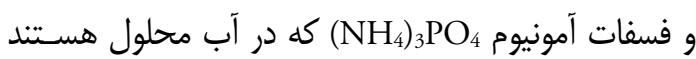

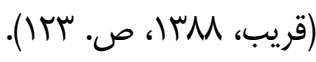

\section{r-Y-Y-Y شكل بناهاى تاريخى}

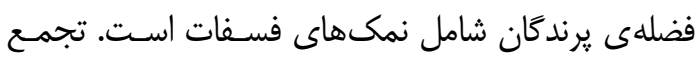
فضله، به فسفاتها كه محلول هستند اجازمى حركت بـ بــانه سطح وسيعترى مىدهد كه تحـت شـرايط رطوبـت قـرار دارد. منبع ديكرى از نمكهاى فسفاته كودهاى شـيميايى

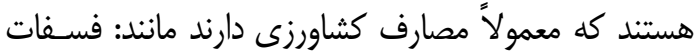

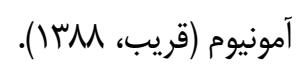

\section{ץ-צ-ץ- بيش ترين و رايجترين اشكال تخريب نمكهاى فسفاته}

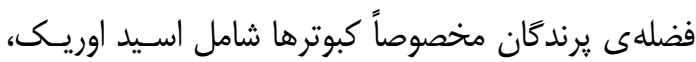

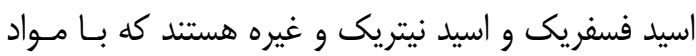



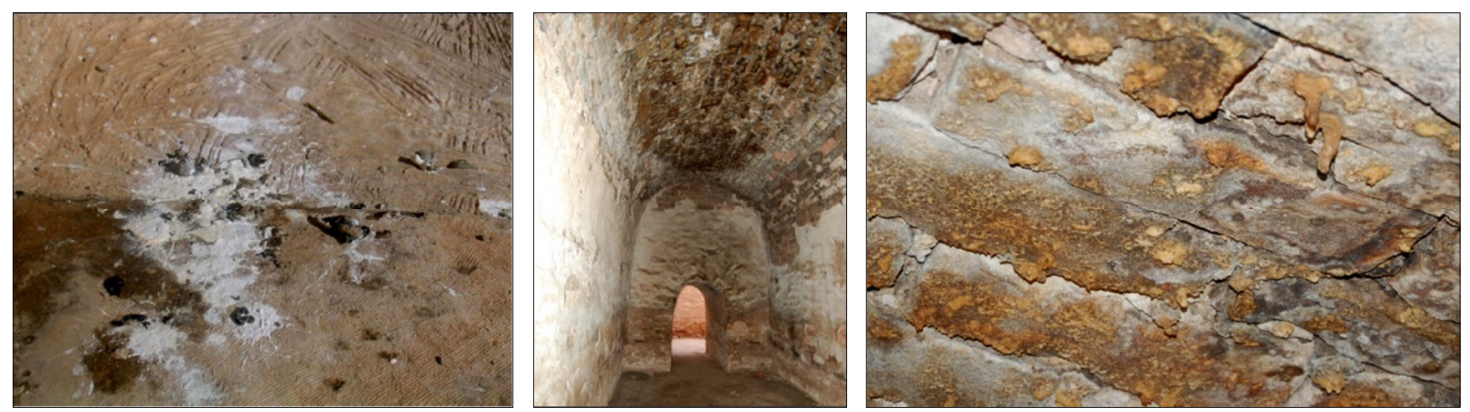

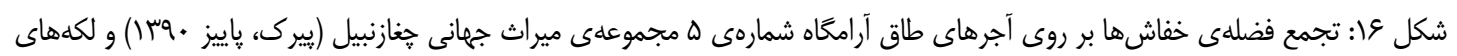

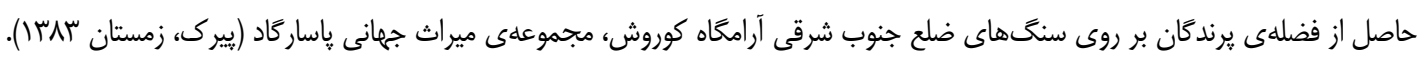

- تخلخل مصالح كه بهخصوص به تفاوت در رفتـار

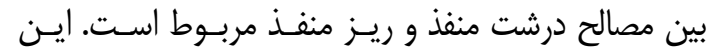

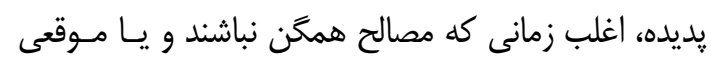

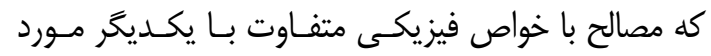
استفاده قرار مى گيرند، اتفاق مىافتد.

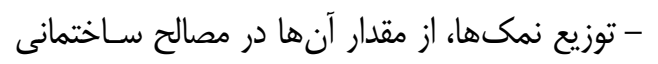

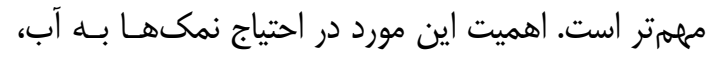

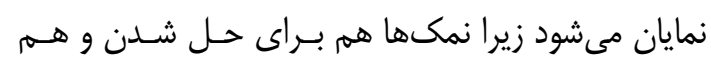

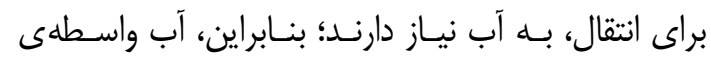

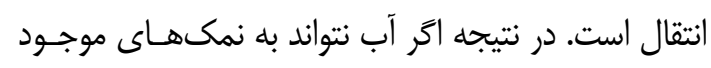

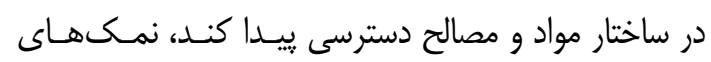

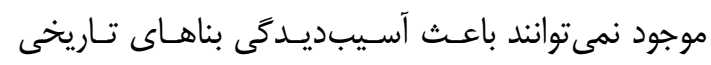
شوند.

فرسايش ناشى از نمكـها معمولاً مربـوط بــهـ امـوال

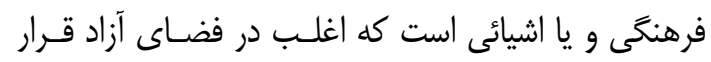

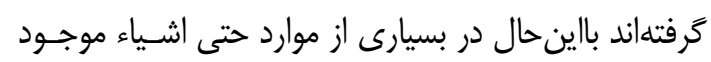

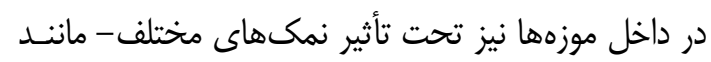

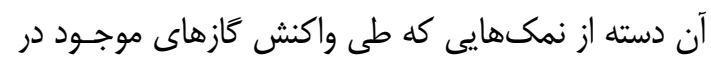

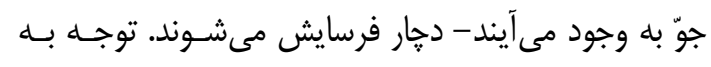

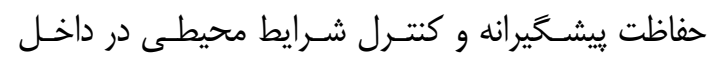

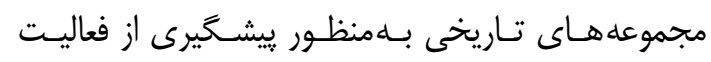

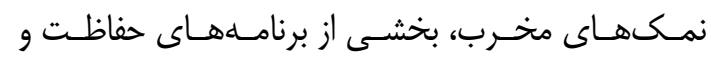

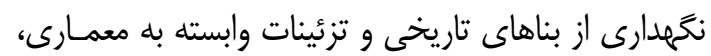

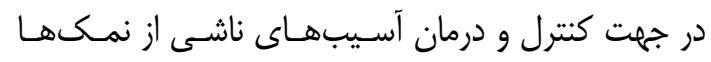

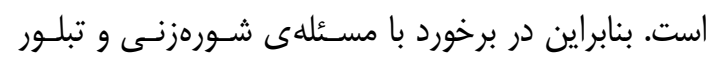

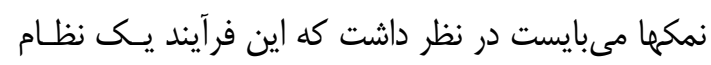

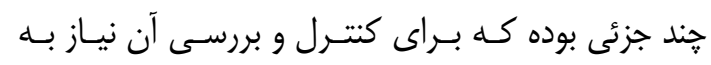

مصالح دارد. پيديدهى شورهزدخى همراه با رفتار و تـأثيرات نمكهاى محلول در حلال، مشكلات زيادى را به همـراه

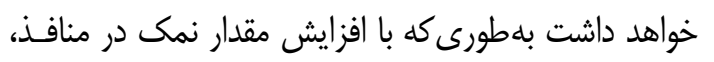

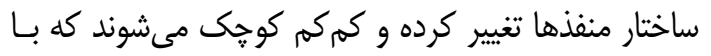

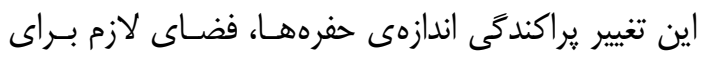

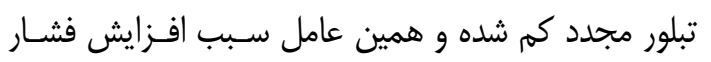

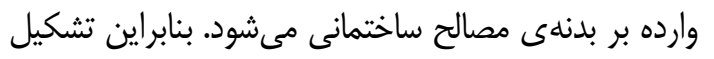

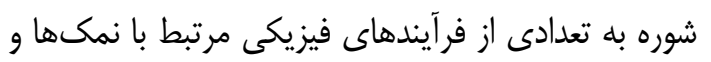

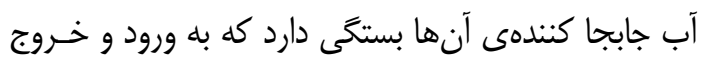

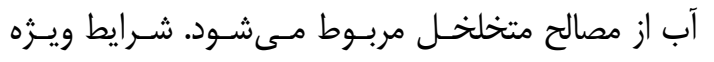

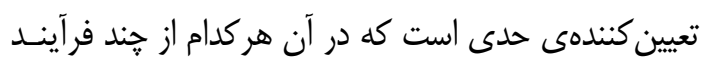

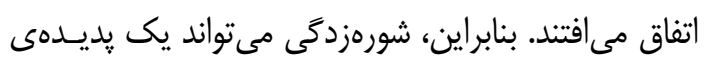

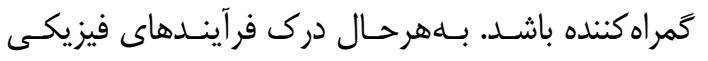
متفاوت مرتبط با موضوع، مىتواند در غلبه بــر بسـيارى از ازئل ناهنجارى هاى ظاهرى مؤثر باشد.

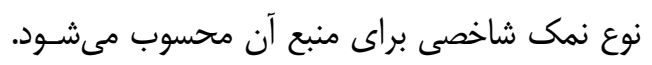

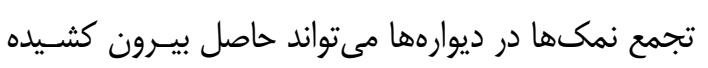

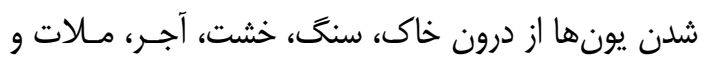

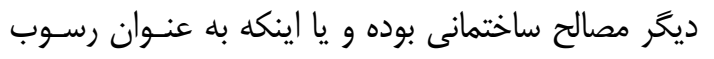

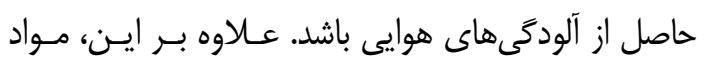

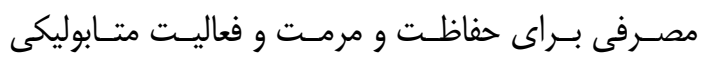

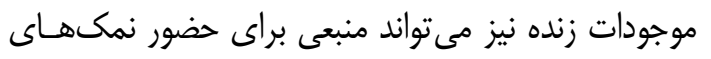
مختلف در ساختار مواد و مصالح باشد. در بناهاى تاريخى، مقدار كمى از نمكىهاى محار محلـول

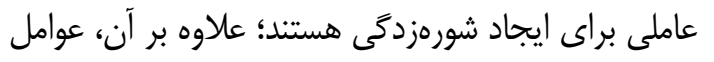

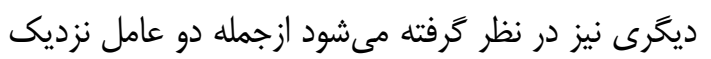
به هم كه به يكديخر وابستهاند، عبارتاند از:

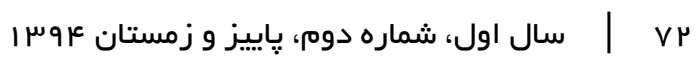


جهت پخت آجر. تهران: مركـز تحقيقـات سـاختمان و

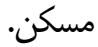

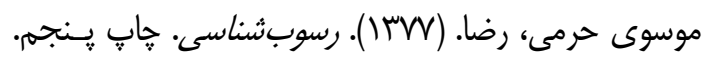

$$
\text { تهران: آستان قدس رضوى رضا. مشهرد. }
$$

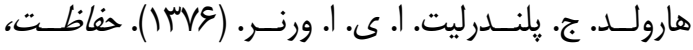

نكهمارى و مرمت آثار هنرى و تاريخى. ترجما: رسول

$$
\text { وطن ودوست. تهران: دانشخاه هنر. }
$$

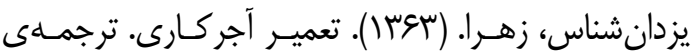

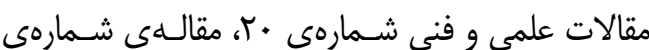

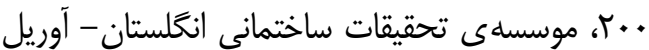

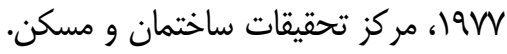

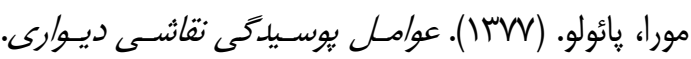

ترجمه: الياس صفاريان و محمدحسـن اثبـاتى. تهـران:

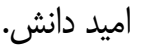

فروتنى، سام. (سربـا). مصالح ساختمانى. تهران: روزنه.

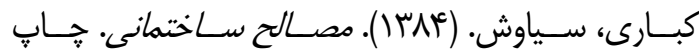

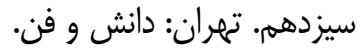

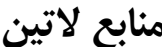

Ahmad, A. G., \& Abdul Rahman, H. F. (2010). Treatment of salt attack and rising damp in heritage buildings in Penang, Malaysia. Journal of Construction in Developing Countries, 15(1), 93-113.

Borrelli, Ernesto. (1999). Salts. Laboratory Handbook. Rom: ICCROM, Unesco.

Brooks, K., Greenshields, J., Loveys, K. (2008). Salt Damp Treatment and Mortar Mixes. Heritage technical note. Adelaide City Council.

Dean, P. A. (2011). The Oxalate Dianion, C2O42-: Planar or Nonplanar?. Journal of Chemical Education, 89(3), 417-418.

Jürgen Schwarz, Hans. Steiger, Michael. (2008). Salzschäden an KulturgüternStand des Wissens und Forschungsdefizite. Ergebnisse des DBU Workshops in Osnabrück. Diese Broschüre wurde hergestellt mit Unterstützung der Deutschen Bundesstiftung Umwelt im Rahmen des Förderprojektes. Hannover.

Young, D., \& Ellsmore, D. (2008). Salt attack and rising damp: a guide to salt damp in historic and older buildings. Heritage Council of NSW; Heritage Victoria; South Australian Dept. for Environment and Heritage; Adelaide City Council.
شناخت كامل اين اجزاء مسىباشــ؛ از طـرف ديخـــ فعـال بودن يا عدم فعاليت منشاء نمك، مـرزى بسـيار حسـاس

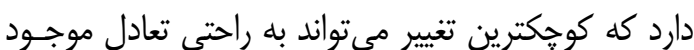
را برهم زند. برهمين اساس برخورد مستقتيم بـا مسـئلهى

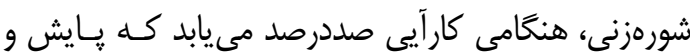

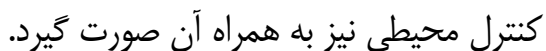

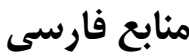

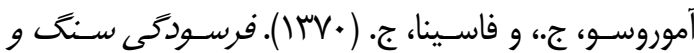

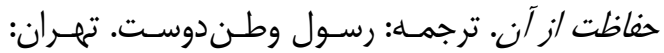

$$
\text { سازمان ميراث فرهنگَى. }
$$

افيونى، مجيد، مجتبــيـور، رسـول، و نـوربخش، فرشـيد.

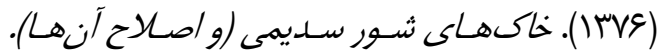

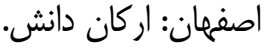

تابش، حسن. (•وس()). حملهى سولفاتهـا بــهـ آجركـارى. مؤسسهى تحقيقات ساختمانى بريتانيـا BRE. مقالـهى

شمارهى 19. مركز تحقيقات ساختمان و مسكن.

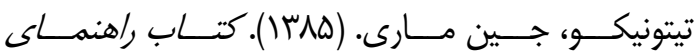

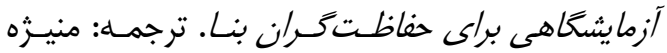
هاديان دهكردى. تهران: هاديان نشر خصوصى.

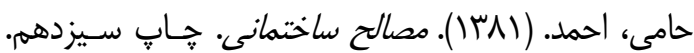
تهران: دانشكاه تهران.

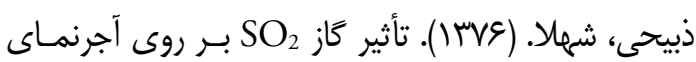

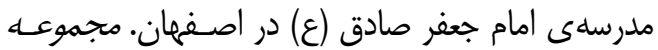
مقالات نخستين همايش حفاظـت و مرمست آثـار

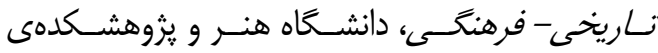
حفاظت و مرمت آثار تاريخى - فرهنكى،

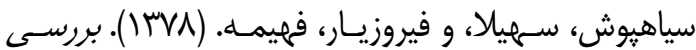

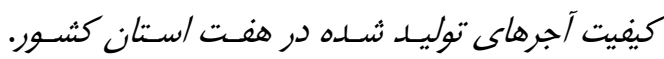
تهران: وزارت مسكن و شهرسازى.

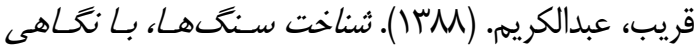

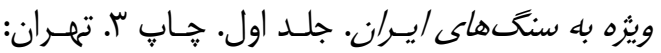
علمى و فرهنكى. ماجدى اردكانى، محمدحسين. (IVD (I). نتايج تحقيقات بـهـ

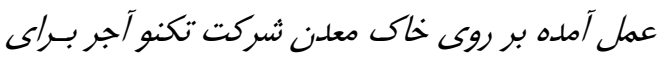
يخت آجر. دومين دورمى آموزشى تعيين كيفيت خـاك 